University of South Carolina

Scholar Commons

$11-2013$

\title{
The Regressing Progress Clause: Rethinking Constitutional Indifference to Harmful Content in Copyright
}

Ned Snow

University of South Carolina - Columbia, snownt@law.sc.edu

Follow this and additional works at: https://scholarcommons.sc.edu/law_facpub

Part of the Law Commons

Recommended Citation

Ned Snow, The Regressing Progress Clause: Rethinking Constitutional Indifference to Harmful Content in Copyright, 47 U.C. Davis L. Rev. 1 (2013)

This Article is brought to you by the Law School at Scholar Commons. It has been accepted for inclusion in Faculty Publications by an authorized administrator of Scholar Commons. For more information, please contact digres@mailbox.sc.edu. 


\section{HEINONLINE}

Citation: 47 U.C.D. L. Rev. 1 2013-2014

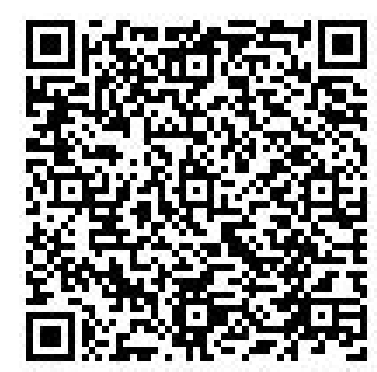

Content downloaded/printed from HeinOnline (http://heinonline.org) Tue Apr 8 12:46:01 2014

-- Your use of this HeinOnline PDF indicates your acceptance of HeinOnline's Terms and Conditions of the license agreement available at http://heinonline.org/HOL/License

-- The search text of this PDF is generated from uncorrected OCR text.

-- To obtain permission to use this article beyond the scope of your HeinOnline license, please use:

https://www.copyright.com/ccc/basicSearch.do? \&operation $=$ go\&search Type $=0$ \&lastSearch=simple\&all=on\&titleOrStdNo=0197-4564 

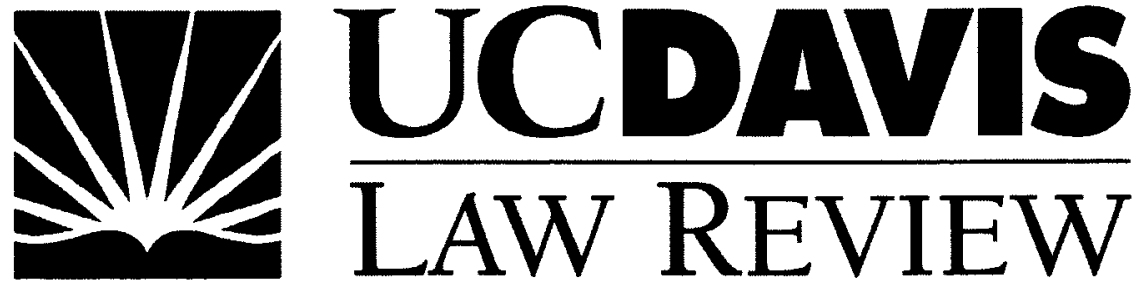

University of California, Davis, School of Law • Vol. 47, No. 1, Nov. 2013

\title{
The Regressing Progress Clause: Rethinking Constitutional Indifference to Harmful Content in Copyright
}

\author{
Ned Snow
}

The Constitution's Progress Clause purports to restrict Congress's copyright power to works that "promote the Progress of Science and useful Arts." For most of the past two centuries, this Clause has set a minimal content-based standard for copyright eligibility. It denied protection for a work whose content did not rise to the level of useful knowledge, in that the work either lacked compositional value or portrayed an immoral or unlawful subject matter. As evidenced by judicial and scholarly writings, this construction of the Progress Clause was consistent with the 1903 decision in Bleistein v. Donaldson Lithographing Co., where the Court warned against judges imposing their own aesthetic values in determining copyright eligibility. In recent years, however, courts and commentators have subtly changed the standard of the Progress Clause from useful

* Copyright 02013 Ned Snow. Associate Professor of Law, University of South Carolina. I thank Professors Ann Bartow, Craig Joyce, David Levine, Michael Madison, Aaron Miller, Dotan Oliar, and Steven Sheppard for their helpful comments in shaping this Article. I am also grateful for helpful comments from the participants of the 2013 Works-In-Progress Intellectual Property Conference. 
knowledge to general knowledge. And some courts have construed the Progress Clause as applying only to the Copyright Act as a whole - not to individual works. These changes in the interpretation of the Progress Clause have led some courts to extend copyright to all subject matter, ignoring the content-restrictive function of the Progress Clause altogether. Yet that function serves a valuable constitutional purpose. Some types of expression fail to promote, and even impede, the progress of science and useful arts. Although standards of progress may change, the law's ability to apply standards should remain constant under the Progress Clause. This Article proposes that the Progress Clause once again serve as a content-based standard for copyright eligibility.

\section{TABLE OF CONTENTS}

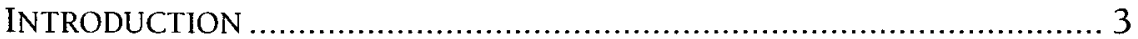

I. THE HISTORY OF SUBSTANTIVE CONTENT RESTRICTION ................ 6

A. The Restrictive Progress Clause ......................................... 7

B. The Expansive Progress Clause .......................................... 10

1. Useful Knowledge ..................................................... 10

2. The Nondiscrimination Principle …………............... 15

3. The Innocence Restraint ........................................... 18

C. Bleistein v. Donaldson Lithographing Co............................ 22

1. Holmes's Majority Opinion ........................................... 23

a. The Progress Clause ……………………………..... 23

b. The Innocence Restraint......................................... 25

c. The Nondiscrimination Principle ………………...... 26

2. Harlan's Dissent .......................................................... 29

3. Opinions After Bleistein .............................................. 30

II. THE MODERN VIEW AND THE ABSENCE OF RESTRICTION ............ 34

A. The Progress Clause as General Knowledge ........................ 35

1. The Rhetoric of Science as General Knowledge........... 37

2. The Purpose of Copyright as Creativity....................... 39

B. The Progress Clause as Unfit for Individual Works.............. 42

1. The Progress Clause as a Preambular Goal................. 42

2. The Progress Clause as a Standard for the Statute...... 46

C. Judicial Rejection of the Innocence Inquiry ............................49

1. Creativity as Copyright's Purpose ……………..............50

2. Necessary and Proper Clause ..................................... 51

III. The Progress Clause AS A STANDARD fOr COPYRIGHTABLE

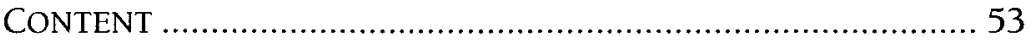

A. A Value-Based Theory of the Progress Clause ...................... 56

B. Narrow and Obvious Limits of Innocence ............................ 57

1. Absence of Social Value............................................... 57 
2. Presence of Social Harm ............................................. 59

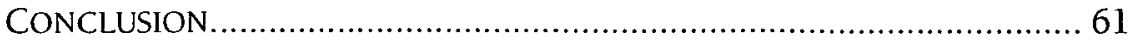

\section{INTRODUCTION}

The Constitution's Progress Clause grants Congress the power "To promote the Progress of Science and useful Arts," by the means of securing copyrights and patents to authors and inventors. ${ }^{1}$ On its face, this power to promote the Progress of Science and useful Arts appears to set a standard for Congress when it awards copyright and patent monopolies. Specifically, the language of the Progress Clause suggests that a work is eligible for a copyright or patent monopoly only if the work promotes the Progress of Science or useful Arts. This standard is apparent in patent law, where the Patent Act requires each invention to manifest indicia of progress through its utility and nonobviousness requirements. ${ }^{2}$ On the copyright side, however, the standard seems absent - or at least modern authorities teach against that standard. ${ }^{3}$ Modern courts and commentators teach against evaluating whether content promotes Progress. ${ }^{4}$ Under this modern view, copyright is entirely blind to content, extending to pornography that is legally obscene, video games that are extremely violent, and music that is hateful toward minorities. ${ }^{5}$ But this modern view suspends practical reason. None of these works seem to promote Progress, and accordingly, none seem constitutionally eligible for a copyright monopoly.

This argument is not new to copyright jurisprudence. For the better part of two centuries, courts routinely denied copyright where a

1 See U.S. CONST. art. I, \& 8, cl. 8. When referring to Progress, Science, and useful Arts as specified in the Progress Clause, I capitalize them. When referring to their meanings generally - not specific to the Progress Clause - I do not capitalize them.

2 See 35 U.S.C. $\S \S 101,103$ (2012). Edward Walterscheid has interpreted statements by the Supreme Court as suggesting that the novelty, nonobviousness, and utility requirements are implicit within the Progress Clause. Edward C. Walterscheid, Divergent Evolution of the Patent Power and the Copyright Power, 9 MARQ. INTELL. Prop. L. REV. 307, 320 (2005) (relying on statements from Bonito Boats, Inc. v. Thunder Craft Boats, Inc., 489 U.S. 141, 151 (1989), and Brenner v. Mason, 383 U.S. 519, 534 (1966)).

3 See infra notes 11, 13-14; see also discussion infra Part II. Although authorities do acknowledge that copyright law requires originality, originality addresses whether a work falls within the meaning of Writings and its creator within Authors of the Intellectual Property Clause. See discussion infra Part II.A.2.

4 See discussion infra Part II.

5 See, e.g., Mitchell Bros. Film Grp. v. Cinema Adult Theater, 604 F.2d 852, 860 (5th Cir. 1979) (extending copyright to legally obscene material). 
work's content offended the Constitution's Progress Clause by failing to "promote the Progress of Science and useful Arts." Indeed, for most of its history, courts read the Progress Clause as requiring expression to be innocent of socially harmful consequences. ${ }^{7}$ This interpretation of the Progress Clause continued well beyond the 1903 Supreme Court decision of Bleistein v. Donaldson Lithographing Co., where the Court forbad judges from invoking aesthetic judgments to determine copyright eligibility, outside of the narrowest and most obvious limits. ${ }^{8}$ Through the latter half of the twentieth century, the Progress Clause represented a content-based limit on copyright - a narrow and obvious limit on Congress's copyright power. ${ }^{9}$

Not until the late twentieth century did courts and commentators change this interpretation of the Progress Clause. ${ }^{10}$ Some now read Bleistein as introducing a virtually absolute bar against any sort of content evaluation, without any practical limits. ${ }^{11}$ Some have construed the focus of the Progress Clause as general knowledge, suggesting that anything creative - regardless of subject matter merits incenting through copyright. ${ }^{12}$ Some interpret "the Progress of

6 E.g., Higgins v. Keuffel, 140 U.S. 428, 431 (1891) ("The use of such labels upon those articles has no connection with the progress of science and the useful arts."); Bullard v. Esper, 72 F. Supp. 548, 548 (N.D. Tex. 1947) ("Copyright provisions . . were never intended to protect illegality, or, immorality. They are for the purpose of promoting the "progress of science and useful arts.'"); Martinetti v. Maguire, 16 F. Cas. 920, 922-23 (C.C.D. Cal. 1867) (No. 9173) (denying copyright on grounds that work was inconsistent with Progress Clause); Clayton v. Stone, 5 F. Cas. 999, 1003 (C.C.S.D.N.Y. 1829) (No. 2872) ("The term science [in the Progress Clause] cannot, with any propriety, be applied to a work of so fluctuating and fugitive a form as that of a newspaper or pricecurrent, the subject-matter of which is daily changing, and is of mere temporary use."); Dane v. M\&H Co., 136 U.S.P.Q. (BNA) 426, 429 (N.Y. Sup. Ct. 1963) ("Where a performance contains nothing of a literary, dramatic or musical character which is calculated to elevate, cultivate, inform or improve the moral or intellectual natures of the audience, it does not tend to promote the progress of science or the useful arts." (citations omitted)); see also Baker v. Selden, 101 U.S. 99, 105-06 (1879) (quoting in dicta the statement quoted supra from Clayton $v$. Stone).

7 See discussion infra Part I.B.

8188 U.S. 239, 250-52 (1903).

9 See discussion infra Part 1.

10 See discussion infra Part II.

11 See, e.g., Diane Leenheer Zimmerman, The Story of Bleistein v. Donaldson Lithographing Company: Originality as a Vehicle for Copyright Inclusivity, in INTEllectual Property Stories 77, 103 (Jane C. Ginsburg \& Rochelle Cooper Dreyfuss eds., 2006) [hereinafter The Story of Bleistein] (describing Bleistein, consistent with a lack of statutory restriction, as effecting a result that "categories of writings . . could virtually never be filtered out by a demand for novelty, creativity or social value").

12 See, e.g., Dotan Oliar, Making Sense of the Intellectual Property Clause: Promotion 
Science and useful Arts" as preambular surplusage - stating a mere goal for Congress without any application to individual works. ${ }^{13}$ And finally, at least one court has construed the Necessary and Proper Clause as excusing any sort of content-based requirement in the Progress Clause. ${ }^{14}$ Through these various interpretations, modern courts and commentators teach against content evaluation in determining copyright eligibility.

In this Article, I explain problems with this reasoning of modern authorities in their construction of the Progress Clause. Part I sets forth the history of the Progress Clause up to the modern interpretation. It recounts nearly two centuries of courts and commentators treating the Clause as a standard for copyrightable content - a standard that offered protection for most content and at the same time discriminated against a narrow class of content that was obviously harmful or uncreative. Part II analyzes the modern misconstructions of the Progress Clause. It focuses on three misconstructions: first, the Progress Clause as focusing on general knowledge; second, the Progress Clause as stating a preambular goal; and third, the Progress Clause as extending to all content under the Necessary and Proper Clause.

of Progress as a Limitation on Congress's Intellectual Property Power, 94 GEO. L.J. 1771, 1809 (2006) [hereinafter Making Sense] (" $[T]$ he eighteenth century meaning of 'science' was close to the meaning of 'knowledge."); L. Ray Patterson \& Craig Joyce, Copyright in 1791: An Essay Concerning the Founders' View of the Copyright Power Granted to Congress in Article I, Section 8, Clause 8 of the U.S. Constitution, 52 EMORY L.J. 909, 947 (2003) (equating Science with learning and rejecting the argument that Science imposes any sort of content-based restriction on the subject matter of copyright); Malla Pollack, Dealing with Old Father William, or Moving from Constitutional Text to Constitutional Doctrine: Progress Clause Review of the Copyright Term Extension Act, 36 LoY. L.A. L. REV. 337, 376 (2002) ("'Science' means 'knowledge' in an anachronistically broad sense."). In another work, I argue that the modern construction of the original meaning of Science in the Progress Clause is historically incorrect. See Ned Snow, The Meaning of Science in the Copyright Clause, 2013 BYU L. REv. 259, 276-306. Evidence suggests the original meaning to be a system of knowledge that derives from branches of study. Id. at 276-77, 306.

13 See, e.g., 1-1 Melville B. Nimmer \& David Nimmer, Nimmer on Copyright $\S 1.03(\mathrm{~A})(2010)$ (" $[\mathrm{T}]$ he phrase 'To promote the progress of science and useful arts [...]' must be read as largely in the nature of a preamble, indicating the purpose of the power but not in limitation of its exercise."); Scott M. Martin, The Mythology of the Public Domain: Exploring the Myths Behind Attacks on the Duration of Copyright Protection, 36 Loy. L.A. L. Rev. 253, 299 (2002) (construing "promote the Progress of Science" as indicating mere purpose without any limiting force on the actual power).

14 See Mitchell Bros. Film Grp. v. Cinema Adult Theater, 604 F.2d 852, 860 (5th Cir. 1979). 
In Part III, I argue that the Progress Clause contemplates judicial consideration of content. I conclude that a correct understanding of the history and doctrine leading up to the modern misconstruction indicates that the Constitution reserves courts an opportunity to deny copyright based on the content of expression. To be clear, I am not arguing that courts should adopt the social norms that they once applied a century ago in deciding copyright eligibility. My argument recognizes that those norms change, and so a present-day application of the Progress Clause must account for present-day values that inform the meaning of promoting Progress. My argument is simply that there is room in the law to apply present-day values. And although I do not fully discuss the particular values and principles that should inform a correct application of the Progress Clause, I briefly summarize some content-specific criteria that courts might apply consistent with the theory underlying, and the history surrounding, the Progress Clause.

\section{THE History OF SUBSTANTIVE CONTENT RESTRICTION}

The Intellectual Property Clause grants Congress power to legislate copyright and patent laws. ${ }^{15}$ It states that Congress shall have power "To promote the Progress of Science and useful Arts, by securing for limited Times to Authors and Inventors the exclusive Right to their respective Writings and Discoveries." 16 The initial phrase of the Intellectual Property Clause, "To promote the Progress of Science and useful Arts" is referred to as the Progress Clause. ${ }^{17}$ In copyright law, the Progress Clause has enjoyed a storied history.

This Part outlines the history of the Progress Clause as a contentbased standard for copyrightable works from the Framing of the Constitution to the late twentieth century. During the first few decades of the Constitution, the Clause imposed a substantial restriction on copyrightable works. As discussed in Section A below, only those subjects that were well established as worthy of study, or in other words, that were fixed, permanent, and durable, were thought to promote the Progress of Science, and so only those subjects could receive a copyright. That restrictive nature of the Progress Clause changed, however, by the mid-1800s. ${ }^{18}$ American culture began to embrace more works of fiction and amusement, and courts responded

15 U.S. CONST. art. I, § 8, cl. 8.

16 Id.

17 See Oliar, Making Sense, supra note 12, at 1772 n.1.

18 See discussion infra Part 1.B. 
by expanding copyright. ${ }^{19}$ Section $\mathrm{B}$ therefore explains how the Progress Clause became much more expansive as courts applied a standard of useful knowledge and a principle of content neutrality. Nevertheless, Section B observes that this more liberal construction of the Progress Clause did not altogether excuse judicial consideration of content: works still needed to exhibit both compositional value and a subject matter that was innocent of immoral effects. These standards existed well beyond the 1903 Supreme Court decision in Bleistein v. Donaldson Lithographing Co., where the Court emphasized that a work's content should not define its eligibility for copyright protection. ${ }^{20}$ Section $\mathrm{C}$ explains how Bleistein did not alter the Progress Clause's standards of compositional value and innocent subject matter.

\section{A. The Restrictive Progress Clause}

The general meaning of science at the Framing captured the means that had yielded so many valuable achievements during the Enlightenment. ${ }^{21}$ From a general perspective, science represented the methodological processes of reason and experience, which would give rise to certainty of conclusions sufficient to merit study. ${ }^{22}$ Through reason and experience, and the subjects of study that arose from them, the new republic had been born. ${ }^{23}$ So science - the intellectual means that had eventually produced their very freedom and liberty - the Framers sought to promote in the Progress Clause. ${ }^{24}$ Science in the Progress Clause accordingly represented the system of knowledge that derives from particular branches of study. ${ }^{25}$ As such, Science concerned the sort of knowledge that would qualify as, or at least derive from, a subject of study. ${ }^{26}$ This meaning of Science in the Progress Clause is apparent from the text of the Progress Clause, the legislative history of that Clause, and various writings of Framers relating to copyright and science. ${ }^{27}$

19 See generally Herbert Ross Brown, The Sentimental Novel In AMERICA 1789 1860 , at 3-8 (1940) (outlining rise of fiction in American history).

20188 U.S. $239,250-52$ (1903).

21 See Snow, supra note 12, at 277-79.

22 See id.

23 See id. at 279.

24 See id at 280

25 See id. at 306.

26 See id.

27 See id. at 276-77. 
To the extent that Science in the Progress Clause dictates the scope of copyrightable subject matter, this meaning of Science suggests a Progress Clause that is highly restrictive, perhaps limited to subject matter that is worthy of study. ${ }^{28}$ This conclusion is consistent with the sorts of works initially registered for copyright protection. ${ }^{29}$ In the decade following the 1790 Copyright Act, the sorts of works that the public registered for copyright most often consisted of instructional manuals or academic material. ${ }^{30}$ Noticeably underrepresented were fictional works of entertainment, which at that time would not have been viewed as subjects worthy of study. ${ }^{31}$

This construction of the Progress Clause is best represented by an 1829 case, Clayton v. Stone. ${ }^{32}$ The opinion was written by a Supreme Court Justice, Smith Thompson, who was sitting by designation in the Southern District of New York. ${ }^{33}$ The issue was whether a catalogue of market prices could receive copyright protection. ${ }^{34}$ Justice Thompson denied protection on constitutional grounds. ${ }^{35}$ He reasoned that because Congress passed the Copyright Act under its copyright power, that Act's purpose necessarily was to promote Science. ${ }^{36}$ Impliedly, then, Justice Thompson viewed Science, rather than useful Arts, as limiting the scope of the copyright power in the Progress Clause. Limiting copyright to the term Science, rather than including useful Arts, Justice Thompson applied a restrictive definition of Science. The meaning of Science, he opined, extended copyright to subject matter that was of a fixed, permanent, and durable character, and nothing less. ${ }^{37}$ In his words: "[I]t would certainly be a pretty extraordinary view of the sciences to consider a daily or weekly publication of the state of the market as falling within any class of them. They are of a

28 See 1 William F. Patry, Copyright Law and Practice 124 (1994) [hereinafter COPYRIGHT LAW AND PRACTICE] ("The meaning of 'science' was not specified by the drafters of the Constitution; early court decisions took a somewhat narrow view of the term."); Snow, supra note 12, at 276-77.

29 Snow, supra note 12, at 300-03 (citing James Gilreath \& Elizabeth Carter Wills, Federal COPYRight ReCORDS $1790-1800$, at xxii (1987)).

30 See James Gilreath \& Elizabeth Carter Wills, Federal Copyright Records 1790-1800, at xxii (1987).

31 See id.

325 F. Cas. 999, 1003 (C.C.S.D.N.Y. 1829) (No. 2872).

33 See id. at 1000 .

34 Id.

35 Id. at 1003 .

36 Id.

37 Id. 
more fixed, permanent and durable character." ${ }^{38}$ His description of Science as exhibiting a "fixed, permanent, and durable character" suggests a subject matter that time has established as worthy of study. Justice Thompson therefore tethered copyright to a restrictive reading of the Progress Clause, consistent with a narrow meaning of Science at the Framing.

Also noteworthy about Justice Thompson's interpretation of the Progress Clause is an explicit recognition that a work's usefulness does not imply its value as a work of Science. In his words: "Although great praise may be due to the plaintiffs for their industry and enterprise in publishing this paper, yet the law does not contemplate their being rewarded in this way; it must seek patronage and protection from its utility to the public and not as a work of science." ${ }^{39}$ In explaining that Science did not examine usefulness, Justice Thompson implied that the Progress Clause applied only Science to copyright - not useful Arts. Had copyright included useful Arts, its scope would have been much more expansive, for it would have extended to that which was only useful without being fixed, permanent, and durable. But that interpretation Justice Thompson expressly rejected. ${ }^{40}$ Thus, a restrictive meaning of Science in the Progress Clause considerably narrowed the scope of copyrightable works. The Progress Clause limited constitutional subject matter to works that were of a fixed, permanent, and durable character, regardless of their usefulness. ${ }^{41}$

This interpretation by Justice Thompson appears to reflect the meaning of Science in the Progress Clause at the Framing. ${ }^{42}$ Indeed, Justice Thompson's interpretation gained further credibility when the Supreme Court later quoted his above-quoted description of the Progress Clause in Baker v. Selden, a case restricting the scope of copyright from extending to systems or processes. ${ }^{43}$ Although the Baker Court's quotation of Justice Thompson appeared in dicta, the Court's quotation emphasized the legitimacy of Justice Thompson's interpretation. $^{44}$

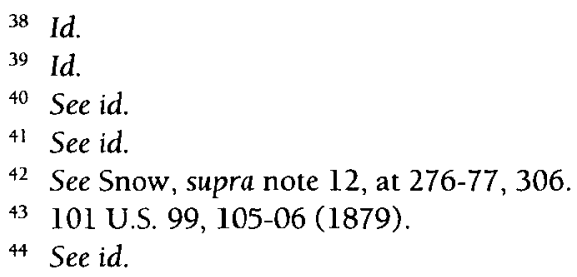




\section{B. The Expansive Progress Clause}

The restrictive view of copyrightable subject matter, as articulated by Justice Thompson in Clayton $v$. Stone, quickly receded as American culture came to embrace works of fiction and entertainment. ${ }^{45}$ As the value of entertainment rose, the subject matter of copyright expanded. The rigid standard that Justice Thompson had set forth under the Progress Clause - that a work must be of a fixed, permanent, and durable character - excluded much expression that the culture valued and thereby demanded. Accordingly, a much more expansive conception of copyrightable subject matter entered the law by the mid- to late-1800s.

The expansion of copyright occurred through two doctrinal changes that affected the construction of the Progress Clause. ${ }^{46}$ First, courts construed the Progress Clause as promoting useful knowledge, thereby requiring a work to merely exhibit minimal value as a composition. ${ }^{47}$ Second, courts warned against discriminating on the basis of content. ${ }^{48}$ These two doctrines greatly expanded the scope of copyright. But that expansion was not without restraint. Certain content remained outside of copyright. ${ }^{49}$ Specifically, courts refrained from extending copyright to works that were immoral or unlawful, upholding a content-based restraint based on a principle of innocence. ${ }^{50}$ This Section outlines the expansion of copyright under the Progress Clause and its corresponding innocence restraint through the nineteenth century.

\section{Useful Knowledge}

Courts expanded the scope of the Progress Clause by evaluating the usefulness of a work rather than its fixed, permanent, and durable

45 See generally BROWN, supra note 19, at 3-8 (observing change in American cultural acceptance of fictional works through the nineteenth century).

46 The scope of copyright also expanded during this time by the Supreme Court's defining Authors and Writings in the Intellectual Property Clause. The Court in Burrow-Giles Lithographic Co. v. Sarony, 111 U.S. 53, 57-58 (1884), adopted an expansive interpretation of Author, "he to whom anything owes its origin," and of Writing, "original intellectual conceptions of the author." This interpretation gives rise to the originality doctrine. Although consistent with the expansion of the Progress Clause, this expansion of Authors and Writings I do not address directly because it did not affect the interpretation of the Progress Clause.

47 See discussion infra Part I.B.1.

48 See discussion infra Part I.B.2.

49 See discussion infra Part I.B.3.

50 See discussion infra Part I.B.3. 
character. The test for whether a work satisfied the Progress Clause became whether it was useful, rather than whether it promoted a field of study as a science. This approach stood in contrast to Justice Thompson's opinion in Clayton v. Stone, where he explicitly rejected utility as a sufficient basis to satisfy the Progress Clause. ${ }^{51}$

The shift to usefulness is evident in case law and commentaries from the nineteenth century. ${ }^{52}$ Perhaps the most exhaustive description of the usefulness requirement may be found in the influential treatise, Drone on Copyright. ${ }^{53}$ In 1879, Eaton Drone wrote the leading authority for copyright law in his time. ${ }^{54}$ Although he gave little analysis of the Progress Clause, Drone did write that Congress enacted copyright laws pursuant to its power "to promote the progress of science." ${ }^{25}$ He further wrote that the purpose of copyright is "to promote learning and useful knowledge." ${ }^{56}$ It would seem, then, that

51 See 5 F. Cas. 999, 1003 (C.C.S.D.N.Y. 1829) (No. 2872); EATON S. Drone, A Treatise on the LaW of Property in Intellectual Productions in Great Britain and the United States, Embracing Copyright in Works of Literature and ART, and Playright in Dramatic and Musical Compositions 209-10 (1879) (portraying Clayton v. Stone as overly restrictive); discussion supra Part I.A.

52 See, e.g., Scoville v. Toland, 21 F. Cas. 863, 864 (C.C.D. Ohio 1848) (No. 12,553) (denying copyright for labels identifying medicine on grounds that "as mere compositions, distinct from the medicine, they are never used or designed to be used"); George Ticknor Curtis, A Treatise on the LaW OF Copyright in BoOKS, Dramatic and MuSical COMPOSITIONS, LETTERS AND OtHER MANUSCRIPTS, ENGRAVINGS and SCUlPture as ENaCted and Administered in ENGLAND and AMERICA; With SOME NOTICES OF THE HISTORY OF LITERARY PROPERTY 147-48 (1847) (describing one of the first questions that courts undertake in considering permissible subject matter of copyright to be whether a publication is useful).

${ }_{53}$ See Drone, supra note 51, at 181.

54 Modern scholars have recognized the authoritative standing of Drone's treatise. See, e.g., Oren Bracha, The Ideology of Authorship Revisited: Authors, Markets, and Liberal Values in Early American Copyright, 118 YALE L.J. 186, 207 (2008) (describing Drone's copyright treatise as "highly influential"); Jessica Litman, The Invention of Common Law Play Right, 25 BERKElEY TECH. L.J. 1381, 1410-16 (2010) (portraying Drone as authoritative scholar during nineteenth century); Michael J. Madison, The End of the Work as We Know It, 19 J. InTELl. Prop. L. 325, 335 n.31 (2012) (characterizing Drone's treatise as "influential"); Peter S. Menell, In Search of Copyright's Lost Ark: Interpreting the Right to Distribute in the Internet Age, $59 \mathrm{~J}$. COPYRIGHT SOc'Y U.S. 1, 35 (2011) (describing Drone as "a leading authority on nineteenth century copyright"); L. Ray Patterson, Understanding the Copyright Clause, 47 J. COPYRIGHT SOC'Y U.S. 365, 386 (2000) (describing Drone's treatise as a "nineteenth century classic"); Diane Leenheer Zimmerman, The Statute of Anne and Its Progeny: Variations Without a Theme, 47 Hous. L. REV. 965, 988 n.98 (2010) (describing Drone as "the major American commentator on copyright" (emphasis added)).

55 DRONE, supra note 51, at 209.

56 Id. at 198-99. 
Drone associated Science with learning and useful knowledge. ${ }^{57}$ That is, Drone appears to have viewed useful knowledge as a focus of the Progress Clause.

Useful knowledge, as portrayed by Drone, implies that a work needed to exhibit value as a composition, even if only minimally valuable..$^{58}$ Indeed, according to Drone, the value needed to be little more than "utter insignificance and worthlessness." ${ }^{59}$ The value did not need to contribute to the scholarly fields of literature or science. ${ }^{60}$ In Drone's words:

Many productions without literary or scientific merit are valuable additions to useful knowledge; and such works, not less than those of learning, in the strict meaning of that expression, are within the scope of the copyright law as judicially construed.... [T]hey are contributions to the general fund of knowledge, and are sources of information useful to the public. ${ }^{61}$

Thus, Drone observed the purpose of copyright, as set forth in the Progress Clause, as imposing a usefulness requirement that entailed a minimal degree of compositional value, sufficient to provide useful information in any subject area.

The Supreme Court weighed in on the meaning of the Progress Clause in 1891, when the Court faced the issue of whether labels on

57 Further evidence of Drone viewing useful knowledge as the focus of the Progress Clause is found in the verbiage and structure of his sentence that states the purpose of copyright. He stated: "The object of the law of copyright is to promote learning and useful knowledge by protecting the fruits of intellectual activity." Id. This sentence employs the same verb, to promote, as the Progress Clause, and it follows the same ends-means structure of the Intellectual Property Clause. The structural introduction of the purpose of copyright in the sentence reflects the structural introduction of the purpose of copyright in the Progress Clause.

58 Drone stated:

While the requirements of the law as to the importance or value of a production are so slight that valid copyright will attach to almost any publication, and to many that appear to be of little or no consequence, not every collection of printed words or sentences is entitled to protection. To be worthy of copyright, a thing must have some value as a composition sufficiently material to lift it above utter insignificance and worthlessness.

Id. at 211 .

59 Id.

60 Id. at 209.

61 Id. Drone also stated, "The material inquiry, then, is not whether a production has literary or scientific merit, but whether it may be regarded as a material addition to useful knowledge ...." Id. at 210. 
disappearing-ink bottles were eligible for copyright protection in the case of Higgins v. Keuffel. ${ }^{62}$ The Court concluded that the use of the labels had "no connection with the progress of science and the useful arts." ${ }^{\text {"3 }}$ The basis for this conclusion the Court explained: "To be entitled to a copyright the article must have by itself some value as a composition, at least to the extent of serving some purpose other than as a mere advertisement or designation of the subject to which it is attached." ${ }^{\prime 6}$ The Court contrasted the purpose of the labels designation of ink bottles - with the purposes of instruction and amusement, which latter purposes, the Court explained, would have been sufficiently valuable to satisfy the Progress Clause. ${ }^{65}$ The Court thus read the Progress Clause as requiring minimal value as a composition, much like Drone.

Although the Higgins Court denied protection for the labels under the Progress Clause, its analysis suggests that the Progress Clause was only narrowly restrictive. ${ }^{66}$ This is evident by the Court including the useful Arts term in applying the Progress Clause to copyrightable subject matter. ${ }^{67}$ Including useful Arts suggests a broader scope of subject matter than only Science: with useful Arts, copyright's subject matter concerns not only that which derives from branches of study (Science), but also that which represents its useful applications (useful Arts) ${ }^{68}$ Furthermore, in analyzing whether the labels were useful as compositions, the Higgins Court contemplated amusement as a useful purpose - suggesting a rather lenient standard for usefulness. ${ }^{69}$ This

62 Higgins v. Keuffel, 140 U.S. 428, 430 (1891).

63 Id. at 431.

64 Id.

${ }^{65}$ Id. at 432. Owing to the subject matter of ink labels, the innocence of the work did not arise in Higgins. Hence, the Court's comments that a purpose of amusement would satisfy the inquiry into usefulness do not imply that amusement would satisfy the inquiry into innocence. See id.; discussion infra Part I.B.3.

${ }^{66}$ Other courts viewed the inquiry of usefulness much more stringently than the Higgins Court portrayed it, consistent with the more stringent view of the Progress Clause in Clayton v. Stone, and re-iterated in Baker v. Selden. See, e.g., Lamb v. Grand Rapids Sch. Furniture Co., 39 F. 474, 475 (C.C.W.D. Mich. 1889) (denying protection for catalogue illustrating merchandise on grounds that federal legislation does not recognize copyright in expression serving only trade purposes); Schumacher v. Wogram, 35 F. 210, 211 (C.C.S.D.N.Y. 1888) (denying protection for advertising label containing pictorial illustration).

${ }^{67}$ Higgins, 140 U.S. at 431 ("[L]abels which simply designate or describe the articles to which they are attached ... have no value separated from the articles, and no possible influence upon science or the useful arts." (emphasis added)).

68 See Snow, supra note 12, at 293-94.

69 Higgins, 140 U.S. at $431-32$. 
focus on usefulness, and its lenient application, stands in stark contrast to the Court's statements just twelve years earlier in Baker v. Selden. In Baker, the Court had quoted Justice Thompson's view of Science as a restrictive term in the Progress Clause, including his statement that a work's usefulness to the public does not suggest copyright eligibility as Science under the Progress Clause. ${ }^{70}$ The Higgins Court, then, could have easily rejected copyright in the labels based on the more stringent test described by Justice Thompson and quoted in Baker $v$. Selden. Instead, the Higgins Court introduced a much more lenient standard for the Progress Clause through its usefulness analysis.

Three years after Higgins, a federal judge, James Putnam, of the District of Massachusetts, considered the issue of copyright eligibility in Henderson $v$. Tompkins. ${ }^{71}$ This case is worth noting because it provides a clear explanation of the Progress Clause's usefulness standard, and because the Supreme Court later relied on this case when it issued Bleistein v. Donaldson Lithographing Co ${ }^{72}$ In Henderson, the work at issue was music that concerned topics of current interest. ${ }^{73}$ The defendant argued that the subject matter did not promote the Progress of Science and useful Arts. ${ }^{74}$ In rejecting this argument, Judge Putnam explained the usefulness requirement of the Progress Clause as a lenient standard:

70 See 101 U.S. 99, 105 (1879). The Baker Court quoted Justice Thompson's statements on Science in the Progress Clause, including his conclusion that a work's usefulness does not satisfy the Progress Clause: "Although great praise may be due to the plaintiffs for their industry and enterprise in publishing this paper, yet the law does not contemplate their being rewarded in this way: it must seek patronage and protection from its utility to the public, and not a work of science." Id.

7 Henderson v. Tompkins, 60 F. 758, 762 (C.C.D. Mass. 1894).

72 See 188 U.S. 239, 250 (1903). Judge Putnam decided the Henderson case while Justice Holmes served as a justice on the Supreme Judicial Court of Massachusetts. Compare History of the Federal Judiciary, FED. JUD. CTR., http:/www.fjc.gov/servlet/ nGetInfo?jid=1082\&cid=999\&ctype $=$ na\&instate $=$ na (last visited Sept. 10, 2013) (stating that Justice Holmes served on the Supreme Judicial Court of Massachusetts from 1882 to 1902), with Henderson, $60 \mathrm{~F}$. at 758 (stating opinion date of 1894). During this time, it is possible that Holmes knew of Putnam's copyright opinion: besides the fact that they were close in geographic proximity, Judge Putnam was known for having a "master mind" in deciding "copyright cases of great magnitude." See in Memory of the Honorable William Lebaron Putnam: Proceedings of the Cumberland Bar, Maine and of the United States CirCuit Court of APPEALS For the FIRST CIRCUIT 35 (1933).

73 Henderson, $60 \mathrm{~F}$. at 759, 762-63.

74 Id. at 762 . 
[W] hether we look only at the direct results of what is addressed to the taste, the imagination, or the capacity of being amused, and the enjoyment which immediately follows therefrom, or whether we look further, and consider what is essential to keep the physical, moral, and intellectual powers refreshed, all such have been regarded by the courts, ever since patents or copyrights were authorized by statute, as within the range of utility and the useful arts. ${ }^{75}$

Consistent with Higgins, Judge Putnam employed a broad definition of usefulness, including amusement, enjoyment, and intellectual, physical, and moral refreshment. The music at issue, which concerned topics of current interest and not topics of formal study, was therefore eligible for copyright under the Progress Clause. ${ }^{76}$

\section{The Nondiscrimination Principle}

In conjunction with the minimal requirement of usefulness, courts and commentators of the nineteenth century recognized that substantive evaluation of content is not appropriate for determining copyright eligibility. ${ }^{77}$ This principle was one of nondiscrimination. Courts usually articulated the nondiscrimination principle while setting forth either the originality requirement that flowed from the Writings and Authors terms of the Intellectual Property Clause, or alternatively, merely as a common law principle of copyright - not as a principle deriving from the Progress Clause. ${ }^{78}$ Yet the nondiscrimination principle is important in understanding the Progress Clause for two reasons. First, the history of the nondiscrimination principle gives context to the coterminous expansion of subject matter that the Progress Clause contemplated. Second, the history demonstrates that the later decision of Bleistein $v$. Donaldson Lithographing Co., which emphasized the nondiscrimination

75 Id. at 763.

$76 \mathrm{Id}$.

77 See, e.g., id. (articulating principle of nondiscrimination to recognize copyright in popular lyrics); Folsom v. Marsh, 9 F. Cas. 342, 346 (C.C.D. Mass. 1841) (No. 4901) (Story, J.) (relying on nondiscrimination rationale to recognize copyright in informal correspondence); DRONE, supra note 51, at 210 (explaining nondiscrimination principle).

78 Compare Folsom, 9 F. Cas. at 346 (describing nondiscrimination as common law principle), with Henderson, $60 \mathrm{~F}$. at 763 (describing nondiscrimination as implication of constitutional inquiry of originality, which inquiry arose under BurrowGiles Lithographic Co. v. Sarony, 111 U.S. 53 (1884)). 
principle, did not introduce a new principle that would have affected the Progress Clause. ${ }^{79}$

One of the earliest explanations of the nondiscrimination principle occurred in 1841 when Supreme Court Justice Joseph Story wrote the famous copyright opinion, Folsom v. Marsh. ${ }^{80}$ At issue in Folsom was whether personal letters of George Washington were eligible for copyright protection. ${ }^{81}$ The defendant argued that the letters could not be copyrighted because they were not literary compositions - they were mere correspondence. ${ }^{82}$ This argument Justice Story rejected. ${ }^{83}$ He explained that many letters written in various contexts - business, personal anecdote, and family gossip - embrace critical remarks on valuable subjects, including moral, religious, political, and literary subjects. ${ }^{84}$ In short, Justice Story reasoned that the apparent content and context of letters could mask their value. ${ }^{85}$ He therefore

79 See 188 U.S. 239, 250-51 (1903).

80 See Folsom, 9 F. Cas. at 346. Folsom v. Marsh is of course well known for articulating the fair use doctrine in copyright law. See id. at 348.

81 Id. at 345.

82 Id. "It is objected, in the first place, on behalf of the defendants, that the letters of Washington are not, in the sense of the law, proper subjects of copyright . . because they are not literary compositions, and, therefore, not susceptible of being literary property, nor esteemed of value by the author ....")

83 Id. at 346.

84 Justice Story stated:

It is extremely difficult to say, what letters are or are not literary compositions. In one sense, all letters are literary, for they consist of the thoughts and language of the writer reduced to written characters, and show his style and his mode of constructing sentences, and his habits of composition. Many letters of business also embrace critical remarks and expressions of opinion on various subjects, moral, religious, political and literary. What is to be done in such cases? . . . It is highly probable, that neither Lord Chesterfield, nor Lord Orford, nor the poet Gray, nor Cowper, nor Lady Russell, nor Lady Montague, ever intended their letters for publication as literary compositions, although they abound with striking remarks, and elegant sketches, and sometimes with the most profound, as well as affecting, exhibitions of close reflection, and various knowledge and experience, mixed up with matters of business, personal anecdote, and family gossip. ... . I hold, that the author of any letter or letters, (and his representatives, ) whether they are literary compositions, or familiar letters, or letters of business, possess the sole and exclusive copyright therein; and that no persons, neither those to whom they are addressed, nor other persons, have any right or authority to publish the same upon their own account, or for their own benefit.

Id.

85 Justice Story was not the first to articulate a theory of nondiscrimination. A 
articulated a nondiscrimination rationale regarding the effect of content on copyright eligibility.

This nondiscrimination principle that Justice Story articulated in Folsom v. Marsh appears in a then-contemporary copyright treatise written by George Curtis, which was the first copyright treatise in the United States ${ }^{86}$ Curtis explained in his 1847 treatise that a work's "value in a critical point of view, can have no influence upon his title to a copyright." ${ }^{\text {"87 }} \mathrm{He}$ also recognized copyright regardless of "whether a book be more or less useful, more or less successful, or brilliant, or important ...." ${ }^{88}$ Hence, Curtis subscribed to the view that copyright should not discriminate based on a critical evaluation of a work's content.

Eaton Drone also articulated the principle of nondiscrimination in his 1879 copyright treatise. He taught against content evaluation in deciding copyright eligibility, stating: "Whether one production is more or less useful, meritorious, or popular than another, is of no concern to the court, which exercises no functions of criticism." ${ }^{89}$ And as discussed above, Drone rejected the argument that copyrightable subject matter must be limited to productions of literary or scientific merit, again teaching a principle of nondiscrimination. ${ }^{90}$

century earlier, an English Court of Chancery decided whether to recognize copyright in familiar letters. See Pope v. Curl, (1741) 26 Eng. Rep. 608 (Ch.) 608. The Lord Chancellor rejected the argument that the informal nature of a familiar letter should disqualify it for copyright. He stated:

It has been insisted on by the defendant's counsel, that this is a sort of work which does not come within the meaning of the act of Parliament, because it contains only letters on familiar subjects, and inquiries after the health of friends, and cannot properly be called a learned work.

It is certain that no works have done more service to mankind, than those which have appeared in this shape, upon familiar subjects, and which perhaps were never intended to be published; and it is this makes them so valuable; for I must confess for my own part, that letters which are very elaborately written, and originally intended for the press, are generally the most insignificant, and very little worth any person's reading.

Id.

86 CURTIS, supra note 52, at 173. Curtis took an interest in more than copyright, serving as co-counsel for Dred Scott in Dred Scott v. Sandford, 60 U.S. (19 How.) 393, 399 (1856), superseded by constitutional amendment, U.S. CONST. amend. XIV.

87 CURTIS, supra note 52 , at 173 .

88 Id. at 172-73.

89 Drone, supra note 51 , at 210.

90 See id. at 209-10. 
In Henderson v. Tompkins, the 1894 copyright case discussed above, Judge Putnam also explained the nondiscrimination principle. ${ }^{91}$ The defendant argued that the subject matter of a humorous song - topics of current interest - was "too trivial" to receive a copyright. ${ }^{92}$ In rejecting this argument, Judge Putnam explained the nondiscrimination principle and its rationale:

If judicial tribunals could lay down maxims by which to determine judicially what dramatic compositions claimed to be humorous, or to appeal to the sense of humor, are in this particular within or without the copyright act, they would, by demonstration, be in possession of rules which would enable them to be themselves at all times witty, at their own option. The very essence of some kinds of humor is in unexpectedness and lack of proportion; and therefore neither courts nor juries have any certain rule for valuing it . . . ${ }^{93}$

The incompetence of judges and juries at determining the value of humorous content, according to Judge Putnam, was sufficient reason to refrain from engaging in content discrimination. ${ }^{94}$ The role of the judge or jury cannot be to assess the value of the work at issue, so taught Judge Putnam.

Despite his well reasoned articulation of the nondiscrimination principle, it should be noted that Judge Putnam also recognized limits on that principle. ${ }^{95}$ Some content, he observed, could be "so trivial" that a court could, as a matter of judicial sense, deny copyright. ${ }^{96}$ Presumably the labels in Higgins $v$. Keuffel would have exemplified the sort of trivial content, lacking in compositional value, that would not qualify for copyright. ${ }^{97}$ Consistent with the Higgins Court, Judge Putnam recognized that the nondiscrimination principle is not absolute.

\section{The Innocence Restraint}

The Progress Clause thus expanded through judicial focus on usefulness, in conjunction with application of a general

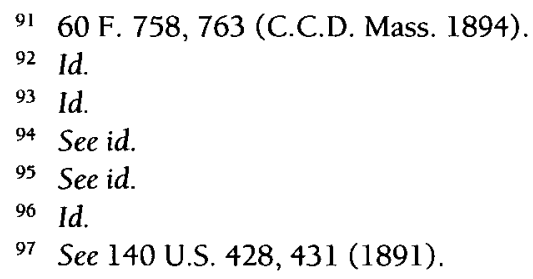


nondiscrimination principle. As discussed above, the inquiry into usefulness examined the value of a work as a composition, and consistent with the nondiscrimination principle, only a minimal degree of compositional value was necessary. ${ }^{98}$ Such minimal compositional value was present where the purpose of the work was merely intellectual refreshment or even amusement. ${ }^{99}$ Albeit a necessity for copyright eligibility, compositional value represented a low bar for establishing useful knowledge in conformity with the Progress Clause. ${ }^{100}$

While compositional value was necessary for satisfying the useful knowledge standard of the Progress Clause, compositional value alone was not sufficient. In addition to compositional value, useful knowledge required that a work not be immoral or otherwise harmful to society. ${ }^{101}$ So at the same time that courts expanded copyright coverage through focusing on compositional value and adopting a nondiscrimination principle, courts also retained a narrowly defined content-based standard. They read the Progress Clause as discriminating against a category of works whose purpose or effect was thought to be harmful. ${ }^{102}$ Stated another way, to be useful, a work needed to be innocent. ${ }^{103}$ The Progress Clause required an innocent subject matter.

Some courts explicitly recognized this standard of innocence under the Progress Clause, while others simply articulated the inquiry as a general common law principle. ${ }^{104}$ One early American jurist who

98 See id.; Drone, supra note 51, at 209-11.

99 See Henderson, $60 \mathrm{~F}$. at 762-63.

100 See discussion supra Part I.B.1.

101 See DRONE, supra note 51, at 112, 181, 185-86 \& n.2 (outlining principle of substantive content restriction and citing to court that relied on Progress Clause to deny protection based on work's content).

102 See id.

103 See id.

104 That commentators and courts portrayed the innocence standard as a principle of common law does not imply that the Progress Clause does not also require it. See, e.g., Broder v. Zeno Mauvais Music Co., 88 F. 74, 79 (C.C.N.D. Cal. 1898) (applying innocence standard under common law). The Intellectual Property Clause reflects common law doctrines of copyright. For instance, courts and commentators have described the originality doctrine as arising under the common law. See Emerson v. Davies, 8 F. Cas. 615, 619 (C.C.D. Mass. 1845) (No. 4436) (Story, J.); Drone, supra note 51, at 198-99. Yet other courts, including the Supreme Court in Burrow-Giles Lithographic Co. $v$. Sarony, framed originality as a constitutional matter, which the words Authors and Writings require. See Burrow-Giles Lithographic Co. v. Sarony, 111 U.S. 53, $57-58$ (1884). Similarly, with respect to the innocence principle, some have described it without reference to the Progress Clause whereas others have relied 
recognized this principle was Justice Joseph Story. ${ }^{105}$ Recall that Justice Story strongly advocated a nondiscrimination principle in Folsom $v$. Marsh: the fact that expression arose in the context of a personal letter, he taught, should not dictate whether the letter was copyrightable. ${ }^{106}$ Years after writing Folsom, Justice Story recognized a content-based restraint in his Commentaries on Equity Jurisprudence. ${ }^{107}$ He wrote: "In the first place, no copyright can exist, consistently with principles of public policy, in any work of a clearly irreligious, immoral, libelous, or obscene description." 108 That which public policy of the time would not want to incent - content of an irreligious, immoral, libelous, or obscene character - Justice Story denied copyright. And as he indicated "in the first place," Justice Story apparently placed this inquiry into a work's innocence before any other inquiry in determining copyright eligibility. ${ }^{109}$

George Curtis recognized this restraint in his 1847 copyright treatise - the same treatise that he articulated the nondiscrimination principle. ${ }^{110}$ On this matter, Curtis devoted an entire chapter of his treatise (twenty pages) to analyzing cases where the character of the work made it ineligible for copyright protection. ${ }^{111}$ The governing principle, Curtis declared, was that copyright does not extend to works that "can be enjoyed only for mischievous purposes or with injury to public morals." 112 And again: "[T]he law declares there can be no property in an immoral, irreligious, or seditious publication ...."113

Eaton Drone wrote extensively on the innocence inquiry in his 1879 treatise ${ }^{114}$ He posed the issue as the first among three chief inquiries that determine whether a work may receive a copyright (the other two being originality and usefulness). ${ }^{115} \mathrm{He}$ summarized the innocence inquiry as follows: "In determining whether a work is entitled to copyright, the courts take cognizance of the question whether it tends

on the Clause to invoke it. See Broder, $88 \mathrm{~F}$. at 79 . But see Martinetti v. Maguire, $16 \mathrm{~F}$. Cas. 920,922 (C.C.D. Cal. 1867) (No. 9173).

105 See 2 JOSEPH STORY, COMMENTARIES ON EQUITY JURISPRUDENCE 603-04 (1884).

106 See Folsom v. Marsh, 9 F. Cas. 342, 346 (C.C.D. Mass. 1841) (No. 4901).

1072 STORY, supra note 105 , at 603-04.

108 Id.

$109 \mathrm{Id}$.

110 See CURTIS, supra note 52, at 147-68.

111 Id.

112 Id. at $148-49$.

113 Id. at 160.

114 See Drone, supra note 51, at 112-14, 181-96.

115 Id. at 181. 
to disturb the public peace, corrupt morals, or libel individuals. A published work, to be entitled to protection, must in the eyes of the law be innocent." ${ }^{116}$ Drone identified three general categories whereby copyright had been withheld on this ground: seditious and libelous works; immoral works; and blasphemous works. ${ }^{117} \mathrm{He}$ did not allude to any sort of tension that this innocence restraint might create with the nondiscrimination principle that he articulated in that same treatise.

One of the more well cited examples of a court invoking the innocence restraint occurred in the case of Martinetti v. Maguire - an 1867 decision by a California federal district court. ${ }^{118}$ The court denied copyright protection for a play that exhibited women in "no dress, and in attractive attitudes." 119 The subject matter lay outside that which the court considered constitutionally permissible under the Progress Clause. ${ }^{120}$ Judge Deady explained:

[C] ongress is not empowered by the constitution to pass laws for the protection or benefit of authors and inventors, except as a means of promoting the progress of 'science and useful arts.' ... [A] dramatic composition which is grossly indecent, and calculated to corrupt the morals of the people... neither 'promotes the progress of science or useful arts,' but the contrary. ${ }^{121}$

Hence, Judge Deady read the Progress Clause as requiring the sort of innocence inquiry that Drone and Curtis described.

It is worth noting that these authorities referred to the innocence inquiry in terms of social morality, but in doing so, they failed to clearly articulate principles that informed the meaning of that morality. Furthermore, that undefined standard of morality ostensibly reflected norms of the nineteenth century. ${ }^{122}$ It seems, then, that the innocence inquiry turned on an amorphous nineteenth-century concept of public morality. Certainly this fact provides reason to argue against applying that substantive standard of morality (or lack thereof) to present-day situations. However, the significance of these cases is

116 Id.

117 Id. at $181-96$.

11816 F. Cas. 920,922 (C.C.D. Cal. 1867) (No. 9173).

119 Id

120 Id.

121 Id

122 See generally Brown, supra note 19, at 3-8 (noting that American culture began to embrace pleasure fiction during the nineteenth century). 
not the particular standard of morality employed. Rather, their significance lies in the mere fact that they recognized content as a basis for denying a copyright monopoly. Their invocation of morality is relevant only to the extent that it demonstrates courts examining content to determine whether expression could be copyrighted.

\section{Bleistein v. Donaldson Lithographing Co.}

In 1903, the Supreme Court decided Bleistein v. Donaldson Lithographing Co., with Justice Oliver Wendell Holmes, Jr. writing the majority opinion. ${ }^{123}$ At issue was whether posters with drawings that advertised a circus were eligible for copyright protection. ${ }^{124}$ In concluding that the posters were indeed copyrightable, Holmes endorsed the expansive view of copyright that several before him had articulated. ${ }^{125}$ He explained that the Progress Clause required a low showing of usefulness and that the nondiscrimination principle should guide the inquiry into originality. ${ }^{126}$ Importantly, in this explanation Holmes never disturbed the innocence restraint of the Progress Clause. ${ }^{127}$ Interpretations that suggest otherwise are textually and historically unsupported. This point is critical as modern commentators and at least one court have missed it. ${ }^{128}$ As I discuss

123188 U.S. 239, 248 (1903).

124 Id.

125 See id. at 249-52.

126 Id.

127 See discussion infra Part I.C.1.c.

128 See, e.g., Mitchell Bros. Film Grp. v. Cinema Adult Theater, 604 F.2d 852, 85556 (5th Cir. 1979) (relying on Bleistein to extend copyright to obscene works); 1 PATRY, COPYRIGHT LAW AND PRACTICE, supra note 28, at 125 (noting a result of Bleistein to be the expansion of copyright "to encompass virtually any work that meets the standard of originality regardless of content or purpose"); Zimmerman, The Story of Bleistein, supra note 11, at 103 (describing Bleistein, consistent with a lack of statutory restriction, as effecting a result that "categories of writings . . . could virtually never be filtered out by a demand for novelty, creativity or social value"); Bracha, supra note 54, at 206 (opining that Martinetti v. Maguire, 16 F. Cas. 920 (C.C.D. Cal. 1867) (No. 9173), which applied the innocence restraint, stands in "stark contrast" to Bleistein and its content-neutral stance); $c f$. Robert A. Gorman, Copyright Courts and Aesthetic Judgments: Abuse or Necessity?, 25 COLUM. J.L. \& ARTS 1, 1-2 (2001) (noting tension between Bleistein and courts that judge artistic works based on social value); Alfred C. Yen, Copyright Opinions and Aesthetic Theory, 71 S. CAL. L. Rev. 247, 248-50 (1998) (observing illusory distinction that courts draw between impartial legal reasoning, and citing to Bleistein for this proposition, and impermissible artistic judgments in deciding copyright cases). But see Steven Hetcher, The Kids Are Alright: Applying a Fault Liability Standard to Amateur Digital Remix, 62 FLA. L. Rev. 1275, 1298 (2010) (endorsing view that the Bleistein nondiscrimination principle does not mean "that the copyrightability of a work should not discriminate against some forms of content as 
below, both the majority opinion and the dissent, as well as case law and treatises following Bleistein, all indicate that Justice Holmes did nothing to upset the Progress Clause's criteria for copyright eligibility.

\section{Holmes's Majority Opinion}

Most of the majority opinion emphasized the nondiscrimination principle. ${ }^{129}$ Holmes only briefly touched upon the Progress Clause, and with respect to the innocence restraint, he was completely silent. ${ }^{130}$ Yet as the subsections below explain, these aspects of Holmes's opinion are consistent with construing the Progress Clause as requiring both the inquiries into compositional value and innocence.

\section{a. The Progress Clause}

Consistent with his style of writing short, pithy, and often cryptic opinions, ${ }^{131}$ Holmes provided only brief analysis of the posters under the Progress Clause - two sentences in all. ${ }^{132}$ Yet those sentences are revealing:

We shall do no more than mention the suggestion that painting and engraving, unless for a mechanical end, are not among the useful arts, the progress of which Congress is empowered by the Constitution to promote. The Constitution does not limit the useful to that which satisfies immediate bodily needs. ${ }^{133}$

Holmes's assertion that "useful arts" extends beyond "a mechanical end" indicates that the useful Arts term applies as much to copyright as to patent. Tellingly, Holmes did not even mention Science, presumably because Science represented the more stringent term in the Progress Clause, at least according to the earlier Supreme Court case of Baker v. Selden, which quoted Justice Thompson's rhetoric

\footnotetext{
compared to others").

129 See Bleistein, 188 U.S. at 249-52.

130 Id.

131 See G. Edward White, Justice Holmes and the Modernization of Free Speech Jurisprudence: The Human Dimension, 80 CALIF. L. REV. 391, 412 (1992) (describing Holmes's opinions as "arresting, memorable, and pithy, but often cryptic, elusive, and sometimes even deceptive as doctrinal formulations").

132 See Bleistein, 188 U.S. at 249.

133 Id.
} 
from Clayton v. Stone. ${ }^{134}$ So Holmes recognized the less-stringent standard of usefulness in the Progress Clause. ${ }^{135}$ And the brevity of his reference to this usefulness standard is consistent with prior judicial and scholarly examinations of usefulness in copyright. ${ }^{136}$ More precisely, Holmes's statement that "the useful" extends beyond that which satisfies "immediate bodily needs" comports with the thenestablished view that useful works includes those which provide intellectual refreshment or amusement as their purpose. ${ }^{137}$ In this respect, Holmes's reference to the Progress Clause and its requirement for usefulness is entirely consistent with the Court's analysis of the usefulness requirement in Higgins $v$. Keuffel. Recall that in Higgins the Court denied copyright for ink-bottle labels because they lacked compositional value, but in doing so, the Higgins Court described the usefulness requirement as requiring a minimally valuable compositional purpose. ${ }^{138}$ Hence, Holmes' two sentences in Bleistein merely emphasized the minimal nature of the usefulness requirement that Higgins introduced.

Also consistent with Higgins is the fact that Holmes apparently believed it necessary to even address usefulness. His statement regarding usefulness indicates that the Progress Clause demanded consideration - albeit slight given the low bar for compositional value. ${ }^{139}$ Holmes's consideration of usefulness therefore reflects not only its broadness in application, but also its necessity for copyright eligibility. Indeed, this treatment of the Progress Clause is consistent with the authorities of that time, which included the following: (1) the Higgins Court, three members of which comprised the Bleistein

134 See Baker v. Selden, 101 U.S. 99, 105-06 (1879) (quoting Clayton v. Stone, 5 F. Cas. 999, 1003 (C.C.S.D.N.Y. 1829) (No. 2872)).

135 Bleistein, 188 U.S. at 249.

136 See discussion supra Part I.B.1.

137 See Higgins v. Keuffel, 140 U.S. 428, 431-32 (1891); Henderson v. Tompkins, 60 F. 758, 762-63 (C.C.D. Mass. 1894); DronE, supra note 51, at 211.

138 Compare Bleistein, 188 U.S. at 249 (providing mere two-sentence analysis of Progress Clause), with Higgins, 140 U.S. at $431-32$ (explaining minimal degree of usefulness necessary to satisfy Progress Clause).

139 Not everyone agrees with this conclusion. See 1 PATRY, COPYRIGHT LAW AND PrACTICE, supra note 28, at 126 ("Bleistein did not, however, reach the issue of whether each individual work must itself promote the progress of science in order to be protectible [sic]."); R. Anthony Reese, Is the Public Domain Permanent?: Congress's Power to Grant Exclusive Rights in Unpublished Public Domain Works, 30 ColuM. J.L. \& ARTS 531, 538 (2007) (interpreting the two quoted sentences above from Bleistein as indicating that the Bleistein Court did not interpret the Progress Clause as limiting Congress's copyright power). 
majority; ${ }^{140}$ (2) Eaton Drone, whom Justice Holmes cited in the Bleistein opinion; ${ }^{141}$ and (3) Judge Putnam, whose copyright opinion, Henderson v. Tompkins, Justice Holmes also cited in the Bleistein opinion. ${ }^{142}$ Thus, in the two sentences addressing the Progress Clause, Holmes both rejected the more stringent view of the Progress Clause as set forth in the dicta of Baker v. Selden and at the same time endorsed the necessity of considering that Clause, as set forth in the holding of Higgins v. Keuffel. ${ }^{143}$

\section{b. The Innocence Restraint}

As discussed in the subsection above, Holmes's brief discussion of the Progress Clause was limited to its usefulness inquiry. He never addressed any inquiry into innocence. He was silent, presumably because the posters that advertised the circus were innocent. This is consistent with the practice of courts of that time, which did not usually raise the issue of innocence unless content crossed the line. ${ }^{144}$ Holmes's silence, then, should not be construed as suggesting that he was overturning that inquiry. Rather, his silence suggests the status quo.

It might be argued, however, that in view of the content under consideration, Holmes's silence suggests that he overruled the innocence restraint. ${ }^{155}$ In particular, one of the posters portrayed women dancing as ballerinas, and the picture exposed the upper portion of several breasts and much of their legs. At that time, the innocence of this picture may have been questionable, a fact that the district court suggested. ${ }^{146}$ So, does the apparent disrepute of this

140 Higgins, 140 U.S. at $431-32$.

141 Bleistein, 188 U.S. at 250; DRONE, supra note 51, at 181, 211.

142 Bleistein, 188 U.S. at 250 ; Henderson, $60 \mathrm{~F}$. at 763.

143 Compare Bleistein, 188 U.S. at 249 (providing summary analysis of Progress Clause), with Baker v. Selden, 101 U.S. 99, 105-06 (1879) (quoting Justice Smith Thompson's restrictive view of the Progress Clause), and Higgins, 140 U.S. at 431-32 (describing Progress Clause as requiring only minimal usefulness).

144 See generally 2 STORY, supra note 105, at $240 \mathrm{n} .5$ (advocating against innocence restraint where there is doubt).

145 Cf. 2 William F. Patry, Patry on Copyright \& 3:42 (2013) [hereinafter Patry ON COPYRIGHT] (interpreting Bleistein District Court as denying copyright on innocence grounds, and interpreting Bleistein Supreme Court as contrasting that grounds for denial by adopting objective approach).

146 The district court's description tacitly raises the question of innocence:

That the picture which represents a dozen or more figures of women in tights, with bare arms, and with much of the shoulders displayed, and by means of which it is designed to lure men to a circus, is in any sense a work of the fine arts, or a pictorial illustration in the sense of the statute, 1 [do] 
poster indicate that Holmes did ignore, and thereby tacitly overturn, the innocence inquiry?

This seems unlikely. Mere silence would not be accorded the weight of overturning a well-accepted doctrine. Rather, the silence suggests only that the doctrine did not apply to the facts under consideration. It is possible that social values of the time had changed by 1903 in comparison to earlier nineteenth-century case law, such that society would not have considered that picture objectionable. ${ }^{147}$ Changing social views on objectionable content might not have raised the issue of innocence. Indeed, even if the content was objectionable during that time, the degree of social objection may not have risen to the level where a discussion was appropriate. ${ }^{148}$ Holmes's silence might therefore suggest that a work's innocence should be questioned only where content clearly calls for it. His silence implicitly suggests that content that merely raises suspicion does not call for restraint, in contrast to content that unquestionably crosses the line. This teaching finds support in the writings of Justice Story. Story explained only a few decades before Bleistein that where doubt exists as to whether a work fails the innocence inquiry, copyright should not be withheld. ${ }^{149}$ Hence, Holmes's choice not to address the poster's innocence may suggest a conservative application of that restraint, consistent with the view of Story.

\section{c. The Nondiscrimination Principle}

Bleistein is perhaps most well known for its articulation of the nondiscrimination principle. ${ }^{150}$ This principle Holmes set forth in

not believe.

Bleistein v. Donaldson Lithographing Co., 98 F. 608, 611 (D. Ky. 1899).

147 The possibility that social mores had made the picture entirely unobjectionable is doubtful. Public reaction to the Bleistein decision indicates otherwise: In the Chicago Record-Herald, the day after Holmes announced Bleistein, the newspaper published a cartoon depicting Holmes pointing to various pictures of dancing women with the caption, "THE SUPREME COURT SAYS THEY ARE ALL RIGHT." See CHI. RECORD-HERALD, Feb. 3, 1903, available at http://copy.law.cam.ac.uk/cam/tools/ request/show Representation?id=representation_us_1903a).

148 That Holmes recognized the questionable content of the circus posters is apparent in his later writings, where he explained that the Bleistein decision upheld "the cause of low art . . . a poster for a circus representing décolletés and fat legged ballet girls." Sheldon M. NOVick, Honorable Justice: The Life of Oliver Wendell HOLMES 254 (1989). Apparently, however, the questionable content did not rise to a level that would have invoked the innocence inquiry.

149 See 2 STORY, supra note 105 , at 604 n.1.

150 See, e.g., I Patry, Copyright LaW and Practice, supra note 28, at 125 ("Justice 
discussing the originality doctrine and the governing Copyright Act. ${ }^{151}$ Holmes stated:

It would be a dangerous undertaking for persons trained only to the law to constitute themselves final judges of the worth of pictorial illustrations, outside of the narrowest and most obvious limits. At the one extreme some works of genius would be sure to miss appreciation.... At the other end, copyright would be denied to pictures which appeal to a public less educated than the judge. ${ }^{152}$

Some modern courts and commentators interpret this declaration of nondiscrimination as a novel development in copyright, the effect of which was to preclude consideration of innocence altogether. ${ }^{153}$ But the evidence indicates otherwise. As an initial matter, Holmes did not invent the nondiscrimination principle; it was already a part of the law. Holmes's declaration of nondiscrimination in the above quotation echoes the statements of others before him. ${ }^{154}$ It draws support from Justice Story's argument for extending copyright to even informal correspondence. ${ }^{155}$ It reflects the admonition of both George Curtis and Eaton Drone that a critical examination of a work's substance should not influence copyright eligibility. ${ }^{156}$ It advocates Drone's sentiment that a work's popularity (or lack thereof) should not matter in copyright determinations. ${ }^{157}$ It articulates the specific warning of Judge Putnam that judges are incompetent at evaluating the worth of a work's content. ${ }^{158}$ Therefore, Holmes's sermon against content discrimination reflects the view of prior jurists and scholars. Certainly

Holmes's opinion . . . enunciated what has become known as the nondiscrimination principle."); Michael W. Carroll, Copyright's Creative Hierarchy in the Performing Arts, 14 VAND. J. ENT. \& TECH. L. 797, 812 (2012) ("Justice Holmes . . announced the now-famous non-discrimination principle in [Bleistein] . . .."); Rebecca Tushnet, Worth a Thousand Words: The Images of Copyright, 125 HARV. L. Rev. 683, 712-13 (2012) ("Most readings of Justice Holmes's 'dangerous undertaking' sentence take it to establish a broad nondiscrimination principle, such that copyright should not make judgments about artistic value.").

151 See Bleistein v. Donaldson Lithographing Co., 188 U.S. 239, 250-51 (1903).

152 Id. at 251-52.

153 See sources cited supra notes 128 and 145 .

154 See discussion supra Part I.B.2.

155 See Folsom v. Marsh, 9 F. Cas. 342, 346 (C.C.D. Mass. 1841) (No. 4901) (Story, J.).

156 See CuRTIS, supra note 52, at 173; DRONE, supra note 51, at 210.

157 See Drone, supra note 51, at 210.

158 See Henderson v. Tompkins, 60 F. 758, 763 (C.C.D. Mass. 1894). 
the nondiscrimination principle of Bleistein was emphatic, but it was not revolutionary.

Because Holmes's articulation of the nondiscrimination principle was not novel, it would not be seen as upsetting the doctrines that determined copyright eligibility. In particular, it would be viewed as consistent with the test for innocence under the Progress Clause. Indeed, prior to Bleistein, there is no indication of any tension between the nondiscrimination principle and the innocence restraint. To the contrary, Justice Story and Eaton Drone each addressed both the nondiscrimination principle and the innocence restraint, and their treatment of these distinct doctrines indicates the compatibility of these doctrines. Story articulated the nondiscrimination principle in his 1841 decision of Folsom v. Marsh ${ }^{159}$ and the innocence restraint in his Commentaries on Equity Jurisprudence, published in $1846 .{ }^{160}$ Tellingly, Story omitted any discussion of innocence in Folsom. ${ }^{161}$ That omission does not imply, or even suggest, that innocence considerations were not relevant in determining copyright eligibility, for Story articulated the doctrine of innocence just a few years later in his Commentaries.

Similar to Story's treatment of these doctrines, Drone addressed both the nondiscrimination principle and the innocence restraint in his 1879 treatise. ${ }^{162}$ He portrayed each as consistent with the other. ${ }^{163}$ There was not even a suggestion of tension between the two. ${ }^{164}$ Hence, the consistency between these doctrines as articulated by Story and Drone suggests that if Holmes advocated only the nondiscrimination principle, Holmes was not arguing against the innocence inquiry. If Holmes had intended for his nondiscrimination principle to overturn the innocence inquiry, their consistency in the law up to that point would have required Holmes to have explicitly made the point.

A final piece of evidence supports the view that Holmes's articulation of the nondiscrimination principle is consistent with the innocence restraint. Holmes made clear that the principle had limits. ${ }^{165}$ Even though those limits represented "the narrowest and most obvious limits," Holmes recognized limits. ${ }^{166}$ An example of such a

159 See Folsom, 9 F. Cas. at 346.

160 See 2 STORY, supra note 105, at 241-42.

161 See Folsom, 9 F. Cas. at 346.

162 See Drone, supra note 51, at 181.

163 See id.

164 See id. at 181-213.

165 See Bleistein v. Donaldson Lithographing Co., 188 U.S. 239, 250-52 (1903).

166 See id. 
narrow and obvious limit would have occurred when the Court in Higgins refused to grant copyright for labels. ${ }^{167}$ Consistent with Higgins, then, Holmes expressly recognized a place for content evaluation. So to interpret the nondiscrimination principle as barring any consideration of innocence - even with respect to the narrowest and most obvious of norms - would be to ignore the language of Holmes.

\section{Harlan's Dissent}

The dissent in Bleistein further supports the interpretation that Holmes, in writing for the majority, did not impose a nondiscrimination principle that was absolute, or for that matter, that overturned the innocence restraint. ${ }^{168}$ Perhaps most telling about the dissent is the Justices who did not join it. Recall that twelve years earlier the Court unanimously decided Higgins, which struck down copyright for lack of usefulness in ink-bottle labels. ${ }^{169}$ At the time of Bleistein, four of the Higgins Justices were still on the Court, and three of those four sided with Holmes in the Bleistein majority. ${ }^{170}$ So if Bleistein were overturning Higgins' recognition that the Progress Clause required usefulness, those three Justices would have had to reverse their own precedent. This seems unlikely, especially given that only a few weeks had passed from oral argument (mid-January) to the decision (February 2), and Holmes himself had been on the Court for only a few months. ${ }^{171}$ In short, the circumstances suggest a practical difficulty in construing the majority opinion as reversing the former positions of three Justices in that majority.

Writing the dissent was Justice John M. Harlan, joined by one other justice. ${ }^{172}$ Noteworthy is that Harlan was the only member of the Bleistein Court who had been on the Court long enough to have participated in Baker v. Selden. ${ }^{173}$ As discussed above, the Baker Court

\footnotetext{
167 See Higgins v. Keuffel, 140 U.S. 428, 431-32 (1891).

168 See Bleistein, 188 U.S. at 252-53 (Harlan, J., dissenting).

169 See Higgins, 140 U.S. at 431-32.

170 Those Justices were John Harlan, Melville Fuller, Henry Brown, and David Brewer. See The Oxford Companion to the Supreme Court of the United States 968 (Kermit L. Hall ed., 1992) [hereinafter OXFORD COMPANiON].

171 See Zimmerman, The Story of Bleistein, supra note 11, at 94 n.80.

172 See Bleistein, 188 U.S. at 252 (Harlan, J., dissenting). Justice Joseph McKenna joined Justice Harlan in dissent. Justice McKenna had been on the Court for only five years at that point - not long enough to have participated in Higgins v. Keuffel, decided twelve years earlier. See OXFORD COMPANION, supra note 170, at 966-68.

173 See OXFORD COMPANION, supra note 170, at 968.
} 
had recited Justice Thompson's stringent application of the Progress Clause, under the definition of Science - subject matter that is of a fixed, permanent, and durable character. ${ }^{174}$ So in Harlan's Bleistein dissent, he appears to have employed that more stringent application of the Progress Clause. ${ }^{175}$ In Harlan's words:

The clause of the Constitution giving Congress power to promote the progress of science and useful arts, by securing for limited terms to authors and inventors the exclusive right to their respective works and discoveries, does not, as I think, embrace a mere advertisement of a circus. ${ }^{176}$

This construction of the Progress Clause was much more restrictive than that of Holmes, deeming that Clause unable to "embrace a mere advertisement of a circus." 177 Indeed, although advertising reflected a useful purpose, it did not reflect a character that was fixed, permanent, and durable.

Noticeably absent from Justice Harlan's dissent was any mention or allusion to the moral standing or innocence of the circus posters. ${ }^{178}$ Rather, Harlan focused solely on the advertising purpose of those posters. ${ }^{179}$ Apparently, then, Harlan did not view the posters as sufficiently immoral to raise an innocence argument. Nor did he apparently believe that the majority's decision had altogether upended the innocence restraint. For that matter, if Holmes had been proposing a rule that barred content evaluation - either of usefulness or innocence - Harlan would have had ample authority to raise criticism. ${ }^{180}$ Harlan did not raise the criticism, suggesting that Holmes did not propose the rule.

\section{Opinions After Bleistein}

Court opinions subsequent to Bleistein indicate its effect on the law. Those opinions continued to require both the usefulness and innocence inquiries that the Progress Clause demanded. With respect to the usefulness inquiry, its continued vitality is apparent from postBleistein opinions that recognized Higgins as good law, where the

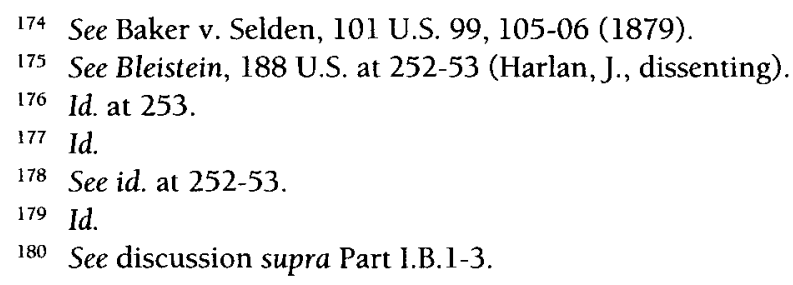


Court explained that inquiry. ${ }^{181}$ For instance, in the 1924 case of Fargo Mercantile Co. v. Brechet \& Richter Co., the- Eighth Circuit considered the effect of both Higgins and Bleistein, and interpreted them to be consistent. ${ }^{182}$ At issue in Fargo was whether commercial labels sold on fruit nectar bottles were copyrightable. ${ }^{183}$ The Eighth Circuit interpreted Higgins as requiring the court to examine the compositional value of the labels, and Bleistein as holding that such value could exist in a work independent of its use for advertising. ${ }^{184}$ After recognizing both Higgins and Bleistein as good law, the Eighth Circuit identified compositional value in the labels that was distinct from its advertising function. ${ }^{185}$

Bleistein also did not affect judicial application of the innocence restraint under the Progress Clause. The month after Bleistein, the federal court for the Southern District of New York in Barnes v. Miner rejected copyright protection for a film of a woman disrobing, the purpose of which was "lascivious and immoral." 186 The exhibition, the court held, was not "of a nature to "promote the progress of science." 187 Assuming that the Barnes court was aware of Bleistein, it did not view Holmes's admonition against content discrimination as undermining the innocence restraint of the Progress Clause. ${ }^{188}$

181 See, e.g., Forstmann Woolen Co. v. J.W. Mays, Inc., 89 F. Supp. 964 (E.D.N.Y. 1950) (relying on Higgins to deny copyright protection for designation labels); Bobrecker v. Denebeim, 28 F. Supp. 383, 384-85 (W.D. Mo. 1939) (denying copyright protection to labels based on Higgins requirement that the labels must contain a valuable purpose, while recognizing its consistency with Bleistein); $c f$. Ansehl v. Puritan Pharm. Co., 61 F.2d 131, 133-36 (8th Cir, 1932) (analyzing case law prior to and after Bleistein to arrive at conclusion that advertising is a proper subject matter of copyright under the constitutional requirement for originality). But see Griesedieck W. Brewery Co. v. Peoples Brewing Co., 56 F. Supp. 600, 606 (D. Minn. 1944) (interpreting Bleistein as setting forth a "more liberal rule" than that articulated in Higgins, yet denying protection for label seemingly based on Higgins).

182295 F. 823, 827-28 (8th Cir. 1924).

183 Id. at 824.

184 Id. at 828.

185 Id. (identifying value in statement of recipes that advanced culinary arts).

186122 F. 480, 489-90 (C.C.S.D.N.Y. 1903)

187 Id.

188 Some commentators have referred to Barnes $v$. Miner in a manner suggesting that Bleistein overturned it. E.g., Zimmerman, The Story of Bleistein, supra note 11, at 89 \& n.62 (citing Barnes in recounting the cases that the Sixth Circuit in Bleistein, which the Bleistein Supreme Court reversed, likely would have been aware of so as to reach its decision to deny copyright protection); see also 1 PATRY, COPYRIGHT LAW AND PraCtiCE, supra note 28, at 126 n.26 (citing Barnes as an example of "early cases" where courts applied the Progress Clause to individual works, in contrast to Bleistein); Bracha, supra note 54, at $206 \& \mathrm{n} .66$ (citing to Barnes as a case that stands in contrast 
Judicial opinions continued to recognize the innocence restraint well into the mid-twentieth century. ${ }^{189}$ In 1947 , for instance, a federal court denied copyright protection on the following grounds: "Copyright provisions ... were never intended to protect illegality, or, immorality. They are for the purpose of promoting the 'progress of science and useful arts."'190 Although some courts did extend copyright protection where a work's innocence was questionable, those courts still addressed the innocence issue, simply concluding that the work did not cross the line of innocence. ${ }^{191}$ In all these cases, courts never portrayed Bleistein as problematic to the inquiry. Bleistein was apparently so far afield from the inquiry of innocence, courts did not even mention it.

Consistent with these judicial opinions, treatise writers in the decades following Bleistein described both the usefulness and

to Bleistein, in the context of describing another case decided prior to Bleistein).

189 See, e.g., Stone \& McCarrick v. Dugan Piano Co., 220 F. 837, 842-43 (5th Cir. 1915) (denying protection for series of advertisements on basis that even if advertisements were copyrightable, they could not be copyrighted if the purpose of their content was to mislead and deceive); Hoffman v. Le Traunik, 209 F. 375, 379 (N.D.N.Y 1913) ("To be entitled to be copyrighted, the composition must be 'original, meritorious, and free from illegality or immorality."').

190 Bullard v. Esper, 72 F. Supp. 548, 548 (N.D. Tex. 1947). Comments of a 1963 New York court are instructive on judicial understanding of the meaning of Science (in an action brought under common law copyright):

Where a performance contains nothing of a literary, dramatic or musical character which is calculated to elevate, cultivate, inform or improve the moral or intellectual natures of the audience, it does not tend to promote the progress of science or the useful arts. Thus, not everything put on the stage can be subject to copyright. While plaintiff's performance was no doubt amusing and entertaining to many, it [is] not ... a production tending to promote the progress of science and useful arts.

Dane v. M\&H Co., 136 U.S.P.Q. (BNA) 426, 429 (N.Y. Sup. Ct. 1963) (citations omitted).

191 See, e.g., Khan v. Leo Feist, Inc., 70 F. Supp. 450, 458 (S.D.N.Y. 1947) ("It cannot be seen that there was a purpose to corrupt the morals of hearers, or to stimulate thoughts or impulses which would otherwise be dormant."), affd, 165 F.2d 188, 192-93 (2d Cir. 1947) ("It seems exaggerated to hold that the rather cheap and vulgar verses would tend to promote lust."); Cain v. Universal Pictures Co., 47 F. Supp. 1013, 1018-19 (S.D. Cal. 1942) (upholding copyright despite disturbing scenes, on grounds that the later scene "destroys all implications of immorality or impiety in the earlier scenes"); Paramore v. Mack Sennett, Inc., 9 F.2d 66, 68 (S.D. Cal. 1925) (recognizing valid purpose of seemingly salacious expression in order to uphold copyright); Simonton v. Gordon, 12 F.2d 116, 124 (S.D.N.Y. 1925) (upholding copyright protection on grounds that an "unnecessarily coarse and highly sensual" work purports to display actual conditions, and was portrayed in a way so as not to encourage lust). 
innocence inquiries without mentioning any tension between that doctrine and the nondiscrimination principle. ${ }^{192}$ One of the most influential treatise writers of the twentieth century was Horace Ball. ${ }^{193}$ He explained the standard of usefulness as encompassing "[i]ntellectual productions which are designed to refresh the physical, mental or moral powers by amusing, entertaining or instructing, or by appealing directly to the aesthetic taste, as well as those subjects which directly serve to inculcate mental discipline or add to the store of knowledge...." 194 Such works, he continued, "are all within the range of 'science and useful arts' as that phrase has been interpreted by the courts." ${ }^{195}$ Hence, Ball viewed the Progress Clause as setting forth the same standard for usefulness under the Progress Clause that courts and commentators prior to Bleistein had articulated.

Ball also demonstrated the continued application of the innocence restraint under the Progress Clause. ${ }^{196}$ Under a section entitled, Works Inimical to Public Morals, his treatise states:

A composition of an immoral character cannot be protected by copyright .... When a suitor invokes the power of the court to protect him in the exclusive right to give public performances of a copyrighted dramatic or musical composition which is grossly indecent, panders to a prurient curiosity, excites an obscene imagination or is otherwise calculated to corrupt the public morals, it is the court's duty to deny him relief upon the ground that such an exhibition or

192 See, e.g., Richard Rogers Bowker, Copyright, Its History and ITS LAW 63, 8687 (1912) (describing copyright works as those which "intellectual labor combines immaterial product into new form," and stating, "[t] here can be no copyright in an immoral book"); Richard C. DE WOLF, AN OUTLINE OF COPYRIGHT LAW 80-82 (1925) (recognizing that "the law gives protection in general to all the writings of authors," and stating, "[i] $t$ is a recognized rule of copyright law, laid down in a number of decisions of the courts, that protection will not be accorded to works of a seditious or immoral character"); ARTHUR W. WEIL, AMERICAN COPYRIGHT LAW 189, 195-96 (1917) (explaining broad subject matter of copyright and noting that "there can be no copyright in any blasphemous, seditious, or immoral, or libelous work").

193 See generally Horace Ball, LaW of Copyright and Literary Property (1944) (leading Ball treatise). See also Harper \& Row Publishers, Inc. v. Nation Enters., 471 U.S. 539, 549 (1985) (relying on Ball to articulate copyright law); Miller Music Corp. v. Charles N. Daniels, Inc., 362 U.S. 373, 375 n.1 (1960) (same); Mazer v. Stein, 347 U.S. 201, 208 n.7 (1954) (same).

194 See BALL, supra note 193, at 67.

195 Id.

196 Id. at 112. 
performance is inimical to "the progress of science and useful arts," which the Copyright Law was designed to promote. ${ }^{197}$

Here, Ball unequivocally portrayed the Progress Clause as precluding copyright for works whose content was immoral. He did not mention any tension between this standard of innocence and the nondiscrimination principle of Bleistein. ${ }^{198}$

\section{THE MODERN VIEW AND THE ABSENCE OF RESTRICTION}

For the better part of two centuries, the Progress Clause served as a content-based standard for individual works to be eligible for copyright protection. ${ }^{199}$ During the latter part of the twentieth century, however, this all changed. Most commentators, and some courts, read the Progress Clause in a way that strips it of any discriminatory force in copyright. This is the result of three misconstructions. The first consists of changing the standard of the Progress Clause from useful knowledge to general knowledge. ${ }^{200}$ As every sort of original expression imparts some sort of knowledge, the modern standard of general knowledge encompasses even that which is not innocent, obscenity and libel for example. ${ }^{201}$ The second misconstruction consists of reading the Progress Clause as stating a preambular goal, or in other words, setting forth constitutional surplusage ${ }^{202}$ Under this interpretation, the Progress Clause does not apply to individual works, such that individual works that are not innocent are copyrightable. ${ }^{203}$ The third misconstruction consists of divorcing the Progress Clause from any sort of innocence inquiry, an approach that the Fifth and Ninth Circuits have adopted. ${ }^{204}$ These three misconstructions I discuss in the sections below.

Although most modern commentators have subscribed to these three misconstructions of the Progress Clause, only a few courts have

197 Id.

198 Ball did observe in another passage that Bleistein's nondiscrimination principle mandates copyright even where popular opinion deems an illustration "grotesque" or "repulsive." Id. at 108 (citing to Bleistein for this proposition). For Ball, the immoral was entirely distinguishable from the grotesque and repulsive, and so the nondiscrimination principle was accordingly distinct from the innocence restraint.

199 See discussion supra Part I.

200 See discussion infra Part 11.A.

201 See discussion infra Part II.A.

202 See discussion infra Part II.B.

203 See discussion infra Part II.B.

204 See discussion infra Part Il.C. 
voiced support. ${ }^{205}$ As illustrated in the sections below, most courts, including the Supreme Court, have remained silent on the ultimate issue of whether the Progress Clause requires innocent content. These misconstructions, then, have only unsettled the historical interpretation. They have not yet taken root as established cannons in copyright.

\section{A. The Progress Clause as General Knowledge}

The focus of the Progress Clause subtly changed from useful knowledge to general knowledge through two interpretive steps. ${ }^{206}$ The first step consisted of courts interpreting the Clause as limiting copyright to the word Science rather than useful Arts. In Graham v. John Deere Co., the Supreme Court in 1966 explained that useful Arts applies to patent, suggesting that Science applies to copyright. ${ }^{207}$ Although the case concerned only patent issues, the Court made clear its bifurcated interpretation of the Progress Clause between copyright (Science) and patent (useful Arts). ${ }^{208}$ The Court re-iterated this interpretation that Science alone governs the scope of copyright in the 2003 decision of Eldred v. Ashcroft and the 2012 decision of Golan v. Holder. ${ }^{209}$ In Eldred, the Court described the copyright power in terms of Science when it quoted only those words from the Intellectual Property Clause relevant to copyright (ellipses and brackets in original): "The Copyright and Patent Clause of the Constitution, Art. I, \& 8, cl. 8, provides as to copyrights: 'Congress shall have Power ... [t]o promote the Progress of Science ... by securing [to Authors] for limited Times ... the exclusive Right to their... Writings."'110 In Golan, the Court stated: "Congress' copyright authority is tied to the progress of science; its patent authority, to the progress of the useful arts." 211

\footnotetext{
205 See cases cited infra note 319.

206 Cf. Michael J. Madison, Beyond Invention: Patent as Knowledge Law, 15 LEWIS \& Clark L. REv. 71, 74-75 (2011) (arguing that current knowledge definition in patent law is inconsistent with the historical meaning of knowledge in patent law).

207383 U.S. 1, 5-6 (1966).

208 Id. at $5 \&$ n.l.

209 See Golan v. Holder, 132 S. Ct. 873, 888 (2012); Eldred v. Ashcroft, 537 U.S. $186,192-93$ (2003). Other modern cases, however, retain useful Arts in describing the purpose of copyright. See, e.g., Campbell v. Acuff-Rose Music, Inc., 510 U.S. 569, 575 (1994) (describing "copyright's very purpose" as " $[\mathrm{t}] \mathrm{o}$ promote the Progress of Science and useful Arts"').

210 Eldred, 537 U.S. at 192-93 (ellipses and brackets in original).

211 Golan, 132 S. Ct. at 888 .
} 
Standing alone, this interpretation does not appear facially problematic. Structurally, the balance and parallelism of the Intellectual Property Clause supports the view that Science corresponds to Writings and Authors, and useful Arts to Inventors and Discoveries. ${ }^{212}$ Substantively, it makes sense that Science represents the source of the knowledge - the subject of copyright - that gives rise to useful Arts or applications - the subject of patent. ${ }^{213}$ Furthermore, this bifurcated construction is consistent with early judicial opinions on the Progress Clause. ${ }^{214}$

At first blush, limiting copyright to Science in the Progress Clause would seem restrictive on the scope of copyright coverage. As discussed above, the original meaning of Science was more restrictive than useful Arts. ${ }^{215}$ Science represented a system of knowledge deriving from branches of study, and required a subject matter that was worthy of study, of a fixed, permanent, and durable character. ${ }^{216}$ Indeed, it appears that nineteenth-century courts began including the useful Arts term as applying to copyright because Science alone was so restrictive ${ }^{217}$ Hence, the modern move to limit copyright to Science would seem more restrictive than including useful Arts.

The modern move, however, had just the opposite effect. As discussed in the subsections below, courts and commentators adopted a meaning of Science that failed to reflect its original restrictive meaning. They redefined Science to mean general knowledge. ${ }^{218}$ Accordingly, by dropping useful Arts and redefining Science, they changed the focus of the Progress Clause from useful knowledge to general knowledge. General knowledge, or learning about any subject, became the constitutional focus of copyright. The ostensible limitation of the Progress Clause - useful, which required both compositional

212 See DE WOLF, supra note 192, at 14-15; Karl B. Lutz, Patents and Science, 18 GeO. WASH. L. ReV. 50, 50-55 (1949). But see Joshua l. Miller, The Unitary Progress Clause: District of Columbia v. Heller and the Structural Interpretation of the Progress Clause, 28 SANTA Clara Computer \& High TeCH. L.J. 241, 242 (2012) (challenging disjunctive interpretation of Progress Clause); Dotan Oliar, The (Constitutional) Convention on IP: A New Reading, 57 UCLA L. REV. 421, 469 (2009) (doubting disjunctive interpretation of Progress Clause).

213 See Snow, supra note 12, at 298 n.144.

214 See, e.g., Clayton v. Stone, 5 F. Cas. 999, 1003 (C.C.S.D.N.Y. 1829) (No. 2872) (Smith, J.) (denying copyright for failure to satisfy the meaning of science); Evans v. Jordan, 8 F. Cas. 872, 873 (C.C.D. Va. 1813) (No. 4564) (reading Progress Clause as applying only useful Arts to patent law).

215 See discussion supra Part I.B.1.

216 See Snow, supra note 12, at 304, 306.

217 See discussion supra Part I.B.l.

218 See Snow, supra note 12, at 266-67. 
value and innocence - no longer existed under the modern misconstruction of the Progress Clause: copyright was limited to Science, and Science meant general knowledge. The two subsections below track this interpretive change through the language of authorities in explaining the meaning of Science and their corresponding focus on creating expression generally as the goal of copyright.

\section{The Rhetoric of Science as General Knowledge}

Modern commentators and courts define the original meaning of Science as general knowledge. ${ }^{219}$ As I argue in another article, this interpretation is lacking for historical support. ${ }^{220}$ The only source that modern authorities ever cite, if any at all, is the first of five entries in the definition of science found in Dr. Samuel Johnson's 1755 Dictionary - knowledge. ${ }^{221}$ But that first entry does not reflect the most common usage at that time. ${ }^{222}$ Indeed, Dr. Johnson ordered the entries in his Dictionary according to their chronological etymology. ${ }^{223}$ Hence, the meaning of Science could have just as well reflected the fifth entry as it could the first. ${ }^{224}$ Nevertheless, over the past few

219 See, e.g., Golan v. Holder, 132 S. Ct. 873 (2012) (treating science as general knowledge); Eldred v. Ashcroft, 537 U.S. 186 (2003) (same); R.W. Beck, Inc. v. E3 Consulting, LLC, 577 F.3d 1133 (10th Cir. 2009) (same); In re Comiskey, 554 F.3d 967 (Fed. Cir. 2009) (same); Infodek, Inc. v. Meredith-Webb Printing Co., 830 F. Supp. 614 (N.D. Ga. 1993) (same); 1 PATRY, COPYRIGHT LAW AND PRACTICE, supra note 28 , at 123 ("The term 'science' as used in the Constitution refers to the eighteenthcentury concept of learning and knowledge."); L. RAY PATTERSON \& STANLEY W. LINDBERG, THE NATURE OF COPYRIGHT: A LAW OF USERS' RIGHTS 48 (1991) ("[T] he word science retains its eighteenth-century meaning of 'knowledge or learning." (emphasis in original)); EDWARD C. WALTERSCHEID, THE NATURE OF THE INTEllectual Property Clause: A STUdy in Historical Perspective 125 (2002) ("The use of the term 'science' [in the Copyright Clause] is straightforwardly explained by the fact that in the latter part of the eighteenth century it was synonymous with 'knowledge' and 'learning.'"); Oliar, Making Sense, supra note 12, at 1809 ("[T] he eighteenth century meaning of 'science' was close to the meaning of 'knowledge."'); Pollack, supra note 12 , at 376 ("Science' means 'knowledge' in an anachronistically broad sense.").

220 See Snow, supra note 12, at 267-71.

2212 Samuel Johnson, a Dictionary of the English Language: In Which the WORdS ARE DEDUCED from ThEIR ORIGINALS, AND Illustrated IN Their Different SIGNIFICATIONS BY EXAMPLES FROM THE BEST WRITERS 1759-60 (lst ed. 1755); see also Snow, supra note 12 , at 262 n.11.

222 See Snow, supra note 12, at 267-68.

223 See 1 JoHnson, supra note 221 , at 6.

224 See Snow, supra note 12, at 267-68. 
decades, courts and commentators have adopted this historically inaccurate meaning of Science - general knowledge. ${ }^{225}$

The move to general knowledge occurred subtly. There was no deliberation or discussion - simply conclusory labels. The first reference of this meaning occurred in a 1952 statement in Senate and House reports. ${ }^{26}$ That statement purported to explain the meaning of Science in the Progress Clause as follows: "[T] he word 'science' in this connection [has] the meaning of knowledge in general, which is one of its meanings today." 227 No support was given for this definition. Subsequently, two law review articles in the 1960s made the same suggestion. ${ }^{228}$ Beyond a reference to Dr. Johnson's Dictionary (as explained in the paragraph above), neither of the two articles provided support for construing Science as general knowledge. Tellingly, both of them made the statements only in passing, focusing primarily on patent law.

The 1973 case of Williams \& Wilkins Co. v. United States represents the first instance where a court proclaimed that Science meant "general knowledge."229 In support of this interpretation, the court relied on one of the law review articles mentioned above and the 1952 legislative history statement also mentioned above - neither of which provided credible support. ${ }^{230}$ Although the court's authority for this proposition was lacking, and although the definition of Science was not necessary for its ultimate decision, the Williams decision became an established authority on the meaning of Science as general knowledge. 231

Since the 1960s and 1970s, commentators have gravitated toward the definition of Science in the Progress Clause as general knowledge, without offering any more support than the one entry from Dr. Johnson's Dictionary and other law review articles. ${ }^{232}$ Courts, too, have

\footnotetext{
225 See sources cited supra note 219.

226 See H.R. REP. No. 82-1923, at 4 (1952); S. REP. No. 82-1979, at 3 (1952).

227 See sources cited supra note 226.

228 See Giles S. Rich, Principles of Patentability, 28 GEO. WASH. L. REV. 393, 396 (1962); Arthur H. Seidel, The Constitution and a Standard of Patentability, 48 J. PAT. OFF. SOC'Y 5, 11-12 \& n.14 (1966).

229 See 487 F.2d 1345, 1382 (Ct. Cl. 1973) ("The word 'Science' lin the Copyright Clause] is used in the sense of general knowledge rather than the modern sense of physical or biological science."), affd by equally divided court, 420 U.S. 376 (1975).

230 Id.

231 See, e.g., 1 Patry, Copyright LaW AND Practice, supra note 28, at $123 \mathrm{n} .12$ (relying exclusively on Williams for the proposition).

232 See sources cited supra notes 219, 221-222.
} 
provided rote recitation of this definition. ${ }^{233}$ In 2003, the Court in Eldred v. Ashcroft explained the public benefit of copyright as "the proliferation of knowledge," which would "[ensure] the progress of science." 234 And in dissent, Justice Breyer explained his belief, which he apparently shared with the majority, that by "Science'... the Framers meant learning or knowledge."235 Most recently in 2012, the Court in Golan v. Holder recited that the petitioners had acknowledged that the "Progress of Science" refers to "the creation and spread of knowledge and learning." 236

Construing the Progress Clause as requiring general knowledge implies that any sort of content is eligible for copyright protection. Any sort of expression that is original gives rise to knowledge and the opportunity to learn of that expression. Any content may be known. So anything goes, even that which traditionally the innocence restraint would have barred.

Importantly, despite these quotations from the Supreme Court, the Court has never held that Science as general knowledge implies that the Progress Clause is blind to content. Its linguistic framing of the Progress Clause in terms of general knowledge has never been a necessary part of its holding. Hence, the statements are dicta. So although its general knowledge language suggests that the Progress Clause is blind to content, it has never held as much. The issue remains unsettled.

\section{The Purpose of Copyright as Creativity}

Modern courts began teaching that the purpose of copyright entails promoting creativity (or originality, which is synonymous with creativity) rather than useful knowledge. ${ }^{237}$ This occurred subtly. In

233 See, e.g., R.W. Beck, Inc. v. E3 Consulting, LLC, 577 F.3d 1133 (10th Cir. 2009) (describing "progress of science" as "knowledge creation and dissemination"); In re Comiskey, 554 F.3d 967, 977 n.9 (Fed. Cir. 2009) ("The Supreme Court has concluded that the references to 'Science' (i.e., knowledge generally) and 'Writings' creates the right to copyright protection . . . ."); Infodek, Inc. v. Meredith-Webb Printing Co., 830 F. Supp. 614, 622 n.8 (N.D. Ga. 1993) ("[T] he use of the term 'science' relates to copyrights and is generally given its eighteenth century meaning of knowledge or learning.").

234537 U.S. 186, 212 n.18 (2003) ("[T]he incentive to profit from the exploitation of copyrights will redound to the public benefit by resulting in the proliferation of knowledge. The profit motive is the engine that ensures the progress of science." (internal quotations and ellipses omitted)).

235 Id. at 243 (Breyer, J., dissenting).

$236 \quad 132$ S. Ct. 873, 888 (2012).

237 Harper \& Row Publishers, Inc. v. Nation Enters., 471 U.S. 539, 545-46, 558 
the 1975 case of Twentieth Century Music Corp. v. Aiken, the Court mentioned in dicta that "the ultimate aim" of copyright is "to stimulate artistic creativity." 238 In 1984, in Sony v. Universal City Studios, the Court declared that the "important public purpose" of copyright is "to motivate the creative activity of authors." 239 A year later, in Harper E Row Publishers, Inc. v. Nations Enterprises Inc., the Court explained the purpose of copyright as increasing the "harvest of knowledge," and that fostering "original works" provided the "seed and substance of this harvest." 240 Further, in Harper, the Court described the purpose of copyright as supplying an incentive "to create and disseminate ideas." 241 In 1991, the Court's language in Feist Publications, Inc. v. Rural Telephone Service Co. described the purpose of copyright as promoting originality, which turns on creativity. ${ }^{242}$ Writing for the majority, Justice O'Connor stated: "The originality requirement articulated in The Trade-Mark Cases and Burrow-Giles remains the touchstone of copyright protection today. It is the very 'premise of copyright law." 243 And later: "The primary objective of copyright is . . ' ' $\mathrm{t}$ ]o promote the Progress of Science and useful Arts.' To this end, copyright assures authors the right to their original expression." 244 Thus, in no uncertain terms the Court has articulated a view of copyright that defines the primary objective of copyright as creativity or originality (which turns on creativity).

Creativity supports the understanding of Science as mere general knowledge because creative expression gives rise to some sort of knowledge, i.e., creative expression adds to the general store of knowledge. Creativity as the focus of copyright therefore implies that copyright exists to promote expression for its own sake. But this makes no sense if the Progress Clause seeks to promote something

(1985).

238422 U.S. 151, 156 (1975); see also Nat'l Cable Television Ass'n v. Copyright Royalty Tribunal, 689 F.2d 1077, 1079 (D.C. Cir. 1982) (relying on Aiken for the proposition that "copyright is intended to encourage the development and dissemination of knowledge by providing incentives to creators"). Prior to this 1975 case, the Copyright Office provided an explanation of copyright emphasizing creativity rather than useful arts. See StafF OF H. COMM. ON THE JudiciarY, 89TH CONG., SUPPLEMENTARY REP. OF THE REGISTER OF COPYRIGHTS ON THE GENERAL REVISION OF THE U.S. Copyright LaW: 1965 Revision Bill 13 (Comm. Print 1965) (explaining that purpose of copyright is to disseminate "creative works").

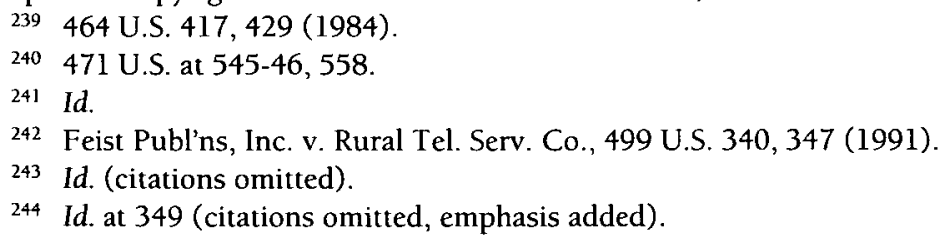


narrower than mere general knowledge. If the Progress Clause requires useful knowledge, not all creative expression necessarily furthers that end. All things creative are not necessarily useful. In particular, content that is not innocent would not have been useful under prior case law, although it may have been creative. Hence, the subtle shift from useful knowledge to creativity (or originality) as the goal of copyright suggests a weakening of the discriminatory force in the Progress Clause because the creativity focus seemingly ignores the innocence restraint.

Of course originality, and thereby creativity, is a constitutional requirement for copyright under the Writings and Authors terms in the Intellectual Property Clause. ${ }^{245}$ This has been well established since Burrow-Giles Lithographic Co. v. Sarony in $1884 .{ }^{246} \mathrm{I}$ am therefore not suggesting that courts are incorrect to emphasize originality under those terms. Nor am I suggesting that courts should not emphasize originality under the Progress Clause, for originality arguably represents the sort of compositional value that the Progress Clause had in the past demanded from individual works. ${ }^{247} \mathrm{I}$ am therefore not arguing against the importance of originality or creativity in copyright. I am arguing against solely focusing on originality, to the detriment of the innocence restraint.

The problem with describing the purpose of copyright as originality or creativity is that this description tacitly disregards the innocence restraint. Recall that for knowledge to be useful under the Progress Clause, it must exhibit an innocent subject matter (in addition to

245 See Burrow-Giles Lithographic Co. v. Sarony, 111 U.S. 53, $57-58$ (1884); see also Feist, 499 U.S. at 346 (interpreting originality requirement of the Copyright Clause to mean that a work "possesses at least some minimal degree of creativity"); The Trade-Mark Cases, 100 U.S. 82, 94 (1879).

246111 U.S. at $57-58$.

247 The equivalence between originality and compositional value is apparent in Higgins v. Keuffel, where the Court described the originality inquiry as an inquiry into "the creative powers of the mind," and then cited the labels at issue as lacking compositional value. See Higgins v. Keuffel, 140 U.S. 428, 431 (1891). The lack of such value, the Court explained, implied the absence of any connection to the Progress of Science and useful Arts. Id. The equivalence is further apparent when comparing Eaton Drone's description of the inquiry into compositional value - one that examines whether there exists "importance or value" that is "so slight" to merit protection - with Judge Putnam's description of the originality inquiry - one that examines whether a work is "so trivial" and "so unimportant" as to merit copyright. Compare DRONE, supra note 51, at 211 (describing inquiry into compositional value), with Henderson v. Tompkins, 60 F. 758, 763 (C.C.D. Mass. 1894) (Putnam, J.) (describing originality inquiry). 
compositional value). ${ }^{248}$ Although creativity does not expressly disavow this innocence restraint, if viewed as the exclusive aim of copyright, creativity could suggest the absence of any other inquiry i.e., the innocence restraint. Relatedly, by reading the creativity inquiry as deriving solely from the Writings and Authors terms, courts appear to entirely ignore the Progress Clause when defining the purpose of copyright. The Progress Clause appears impotent, and accordingly, the innocence restraint becomes altogether lost in the quest for creativity.

\section{B. The Progress Clause as Unfit for Individual Works}

Some courts and commentators have construed the Progress Clause to represent an ineffectual preamble to the actual power granted, lacking any limiting force on congressional power. ${ }^{249}$ Alternatively, some have recognized the Clause as a restriction on congressional power, but only with respect to the overall purpose of the copyright statute - not individual works. ${ }^{250}$ Hence, modern interpretations of the Progress Clause represent it as either an ineffectual preamble or as a limitation on only the purpose of a statute. Either way, the interpretations deny courts the opportunity to apply the Progress Clause to individual works. As discussed in the subsections below, these interpretations contravene the historical construction of the Progress Clause.

\section{The Progress Clause as a Preambular Goal}

Some courts and commentators have construed the Progress Clause as representing a preambular introduction to the copyright power granted to Congress. ${ }^{251}$ They read the Progress Clause as stating a mere goal for Congress, lacking any limiting force on the congressional power granted. This reading suggests that the Progress Clause is analogous to the prefatory clause of the Second Amendment, which does not limit the scope of the remaining operative clause. ${ }^{252}$

\footnotetext{
248 See discussion supra Part I.B.3.

249 See discussion infra Part II.B.1.

250 See discussion infra Part II.B.2.

251 See, e.g., Schnapper v. Foley, 667 F.2d 102, 112 (D.C. Cir. 1981) (rejecting argument that "the introductory language of the Copyright Clause constitutes a limit on congressional power"); NIMMER \& NIMMER, supra note 13, § 1.03(A) (describing Progress Clause as a preamble "indicating the purpose of the power not in limitation of its exercise").

252 See District of Columbia v. Heller, 554 U.S. 570, 577-78 (2008) ("IA] prefatory
} 
The view that the Progress Clause represents an ineffective preamble has attracted well regarded scholars and jurists. David Nimmer, for instance, has labeled the Progress Clause as a preamble, "indicating the purpose of the power but not in limitation of its exercise." 253 Three federal circuits have followed Nimmer's interpretation. ${ }^{254}$ On the other hand, Professor Lawrence Solum has argued that consistency of grammatical structure in all the powers granted Congress under the same section of the Constitution (Article 1 Section 8) precludes a preambular construction of the Progress Clause. ${ }^{255}$ Professor William Patry has echoed this interpretation. ${ }^{256}$ Professor Dotan Oliar has cited historical and textual evidence surrounding proposals at the Constitutional Convention to conclude that the Progress Clause is a limitation on congressional power. ${ }^{257}$ From a textual and historical perspective, these arguments of Professors Solum and Oliar are persuasive.

Although much has been said on this issue by Professors Solum and Oliar, I offer one observation in support of their conclusion that the Progress Clause should not be interpreted as a preamble. Simply put, the very presence of the Progress Clause suggests that it is necessary to

clause does not limit or expand the scope of the operative clause.").

253 See, e.g., NiMMER \& NIMMER, supra note 13, \& 1.03 ("This introductory phrase is in the main explanatory of the purpose of copyright, without in itself constituting a rigid standard against which any copyright act must be measured."). For an insightful critique of David Nimmer, see Ann Bartow, The Hegemony of the Copyright Treatise, 73 U. CIN. L. REV. 581, 584-606 (2004), which argues against judicial practice of relying on Nimmer's treatise without critical inquiry.

254 See Eldred v. Reno, 239 F.3d 372, 378 (D.C. Cir. 2001) (rejecting the argument that "the introductory language of the Copyright Clause constitutes a limit on congressional power"); Hutchinson Tel. Co. v. Fronteer Directory Co. of Minn., 770 F.2d 128, 130 (8th Cir. 1985) ("We agree with Professor Nimmer that although the promotion of artistic and scientific creativity and the benefits flowing therefrom to the public are purposes of the Copyright Clause, those purposes do not limit Congress's power to legislate in the field of copyright."); Ladd v. Law \& Tech. Press, 762 F.2d 809, 812 (9th Cir. 1985) (reciting its precedent as relying on Nimmer for the proposition that "the first phrase of the Copyright Clause expands rather than limits congressional authority").

255 See Lawrence B. Solum, Congress's Power to Promote the Progress of Science: Eldred v. Ashcroft, 36 LOY. L.A. L. REv. 1, 12-25 (2002).

2562 PATRY, PATRY ON COPYRIGHT, supra note 145, \& 3:9 (characterizing the preambular construction as an absurd approach that serves only to "render [the Progress Clause] meaningless, the equivalent of mottos on license plates; that is contrary to the general theory of interpretation that insists on giving every word meaning" and noting that "[n]o clause in Article I, Section 8 has a preamble").

257 See Oliar, Making Sense, supra note 12, at 1810-16. 
define the grant. ${ }^{258}$ Had the Framers believed that copyright would promote the Progress of Science and useful Arts ("promote Progress") as a matter of course, they could have granted Congress the power to legislate copyright without including the Progress Clause. ${ }^{259}$ Apparently, however, the Framers did not hold that belief, as evidenced by the presence of the Clause. Indeed, a fundamental principle of constitutional interpretation is that the presence of a word in the Constitution presumptively indicates its necessity. ${ }^{260}$ And neither the text of the Progress Clause nor its history suggests that the Progress Clause is superfluous. ${ }^{261}$ Without any indication otherwise, the very presence of the Progress Clause suggests that it is not preambular.

The modern Supreme Court has not given clear guidance on this question. From one perspective, the Court in Eldred v. Ashcroft made statements suggesting a preambular interpretation. ${ }^{262}$ These statements occurred when the Court explained the petitioner's argument that the copyright statute under consideration, the Copyright Term Extension Act (CTEA), violated the limited Times language of the Intellectual Property Clause. ${ }^{263}$ The Court stated:

[P]etitioners contend that the CTEA's extension of existing copyrights does not "promote the Progress of Science" as

258 See Snow, supra note 12, at 273; Edward C. Walterscheid, "Within the Limits of the Constitutional Grant": Constitutional Limitations on the Patent Power, $9 \mathrm{~J}$. INTELL. Prop. L. 291, 326 (2002) [hereinafter Within the Limits] (arguing against construing the Progress Clause as preambular in nature because to do so would "render it meaningless," which effect would be "contrary to the well-established principle [of constitutional interpretation]").

259 See Snow, supra note 12, at 273.

260 See generally Marbury v. Madison, 5 U.S. (1 Cranch) 137, 174 (1803) ("It cannot be presumed that any clause in the constitution is intended to be without effect."). Cf. District of Columbia v. Heller, 554 U.S. 570,578 n.8 (2008) (concluding that a clause should be construed as prefatory rather than operative where "the text of a clause itself indicates that it does not have operative effect, such as 'whereas' clauses in federal legislation or the Constitution's preamble").

261 See generally Snow, supra note 12, at 276-306 (examining history and text of Progress Clause).

262 Eldred v. Ashcroft, 537 U.S. 186, 211 (2003). The Eldred Court also employed the term preambular in describing the Progress Clause when it recited the appellate court's holding. Id. at 197 ("[T]he court rejected petitioners' plea . . . with a view to the 'preambular statement of purpose' contained in the Copyright Clause: 'To promote the Progress of Science.' . . . [T]he court took into account petitioners' acknowledgment that the preamble itself places no substantive limit on Congress' legislative power.").

263 Id. 
contemplated by the preambular language of the Copyright Clause. To sustain this objection, petitioners do not argue that the Clause's preamble is an independently enforceable limit on Congress' power. See 239 F.3d, at 378 (Petitioners acknowledge that "the preamble of the Copyright Clause is not a substantive limit on Congress' legislative power."). Rather, they maintain that the preambular language identifies the sole end to which Congress may legislate .... .64

Hence, in describing petitioners' argument, the Eldred Court described the Progress Clause as a preamble within the Intellectual Property Clause.

Yet this verbiage from Eldred does not definitively decide the issue. As an initial matter, the question of whether the Progress Clause constitutes preambular language was not before the Eldred Court. Indeed, a close examination of the Eldred Court's language reveals that in these instances where it described the Progress Clause as a preamble, it qualified those statements as arguments of the petitioner. ${ }^{265}$ Moreover, another opinion of the modern Court casts doubt on whether the Progress Clause is a preamble - Graham v. John Deere Co. ${ }^{266}$ The Graham Court considered whether the Progress Clause limited the scope of patent law. ${ }^{267}$ With respect to Congress's patent power, its language is clear: "The Congress in the exercise of the patent power may not overreach the restraints imposed by the stated constitutional purpose." 268 It also referred to the "constitutional command" to "promote the Progress of... useful Arts" as a

264 Id. (emphases added).

265 See id

266 See Graham v. John Deere Co., 383 U.S. 1, 5-8 (1966). In the Second Amendment context, the Court in District of Columbia v. Heller described the structure of the Second Amendment as a division between an initial prefatory clause and a subsequent operative clause. District of Columbia v. Heller, 554 U.S. 570,577 (2008). That description would reflect the modern construction of the Progress Clause as a preamble to the operative portion of the Intellectual Property Clause - an interpretation with which I disagree. Tellingly, however, the Heller Court noted that "this structure of the Second Amendment is unique in our Constitution." Id. (emphasis added). According to the Heller Court, then, the Second Amendment is the only part of the Constitution containing a preambulary introduction. Of course the Court made this statement in dicta, without any binding effect on the issue of whether the Progress Clause is preambular. But this statement in Heller, along with its statements in Graham, do call into question the forcefulness of the Eldred Court's preamble verbiage as a description of the Progress Clause.

267 Graham, 383 U.S. at 5-8.

268 Id. at 5-6. 
"standard" that "may not be ignored." 269 Therefore, in the patent context, the Court has indicated that the Progress Clause represents a limitation - not a preamble. And if this is so in patent, then interpretive consistency implies it in copyright as well.

Thus, Graham suggests that Eldred should be read cautiously with regard to its preambular language describing the Progress Clause. The issue is at least unsettled. And in the face of the uncertainty that the modern Court has introduced, it seems appropriate to rely on clear precedent from an older Court. That precedent is found in Higgins $v$. Keuffel, where in 1891, the Court employed the Progress Clause to hold that labels could not be copyrighted. ${ }^{270}$ Its reasoning makes no sense if the Progress Clause represented a mere preambular introduction to the copyright power.

\section{The Progress Clause as a Standard for the Statute}

Similar to the modern interpretation that the Progress Clause represents a preamble is the modern interpretation that the Progress Clause represents a limitation on the Copyright Act as a whole rather than on individual works. ${ }^{271}$ Although this interpretation purports to construe the Progress Clause as limiting the authority of Congress, the interpretation does not apply any restriction to individual works. ${ }^{272}$ Rather, this interpretation requires that courts examine the overall system that Congress implements. ${ }^{273}$ Accordingly, the interpretation implicitly extends copyright protection to original works that fail to promote Progress.

${ }^{269}$ Id. Five years following Graham, Justice Douglas commented on the Progress Clause in a dissent from a denial of certiorari in Lee v. Runge:

While this Court has not had many occasions to consider the constitutional parameters of copyright power, we have indicated that the introductory clause, "To promote the Progress of Science and useful Arts," acts as a limit on Congress' power to grant monopolies through patents.

404 U.S. 887, 888-90 (1971).

270 See 140 U.S. 428, 431-32 (1891).

271 See Nimmer \& NimMER, supra note 13, \& 1.03(B) ("Under the currently prevailing view, set forth in Mitchell Bros. Film Group v. Cinema Adult Theater the introductory phrase of the Copyright Clause does not require that each of the 'writings' protected by copyright in fact promote science or useful arts, but only Congress shall be promoting these ends by its copyright legislation."); Oliar, Making Sense, supra note 12, at 1842-44.

272 Oliar, Making Sense, supra note 12, at 1842-44.

273 Id. 
This interpretation finds support in the language of the modern Supreme Court. In Eldred v. Ashcroft, the Court framed the Progress Clause in terms of the statutory system Congress creates: "[t]he primary objective of copyright is ' $[t]$ o promote the Progress of Science.' The 'constitutional command,' we have recognized, is that Congress, to the extent it enacts copyright laws at all, create a 'system' that 'promote[s] the Progress of Science."'274 And in both Eldred and Golan, the Court explained that the Intellectual Property Clause "empowers Congress to determine the intellectual property regimes that, overall, in that body's judgment, will serve the ends of the Clause." 275 Hence, language from Eldred and Golan supports a construction of the Progress Clause that applies to the overall regime.

Although this language from Eldred and Golan represents the Progress Clause as applying to the statutory regime of copyright as a whole, this does not imply that the Progress Clause does not also apply to individual works. Both Eldred and Golan involved a challenge to the statutory regime of the Copyright Act - not a challenge to the copyrightable status of an individual work. ${ }^{276}$ Hence, the Court's statements should not be read to suggest any position on the application of the Progress Clause to individual works. The fact that the Progress Clause is relevant in considering a statutory regime does not imply that the Progress Clause is irrelevant in considering an individual work. It is possible that the congressional limitation of the Progress Clause applies both to the statute as a whole and to individual works.

Whereas neither Golan nor Eldred speaks to whether the Progress Clause applies to individual works, Graham v. John Deere Co. does. In explaining the Progress Clause as it applies to patent law, the Court in Graham observed that the constitutional standard set forth in that Clause applies to individual works. ${ }^{277}$ The Court stated:

[A] patent system ... by constitutional command must 'promote the Progress of . . . useful Arts.' This is the standard expressed in the Constitution and it may not be ignored. And it is in this light that patent validity 'requires reference to a standard written into the Constitution.' . . It is the duty of the Commissioner of Patents and of the courts in the

274 Eldred v. Ashcroft, 537 U.S. 186, 212 (2003) (citations omitted) (brackets in original).

275 Golan v. Holder, 132 S. Ct. 873, 876 (2012) (quoting Eldred, 537 U.S. at 218).

276 See Golan, 132 S. Ct. at 877-78; Eldred, 537 U.S. at 192-93.

277383 U.S. 1, 6 (1966). 
administration of the patent system to give effect to the constitutional standard by appropriate application, in each case, of the statutory scheme of the Congress. ${ }^{278}$

Thus, the Graham Court spoke of a "duty" imposed by the "constitutional command" of the Progress Clause.279 That duty requires courts to "give effect" to that Clause by "appropriate application, in each case." ${ }^{280}$ In other words, the Graham Court required courts to apply the Progress Clause to individual works. ${ }^{281}$ And although it spoke in regards to patent law, interpretive consistency of the Intellectual Property Clause implies the same result in copyright.

Older Supreme Court case law also supports an interpretation of the Progress Clause that applies to individual works. As mentioned above, the Court in Higgins v. Keuffel examined the individual works before it, labels on ink-bottles, to see whether they promoted Progress. ${ }^{282}$ In no uncertain terms, the Higgins Court applied the Progress Clause to individual works. ${ }^{283}$ The Court in Bleistein v. Donaldson Lithographing Co. also referenced the usefulness requirement of the Progress Clause when it considered whether the individual circus posters were copyrightable. ${ }^{284}$ Although the Bleistein Court's statements were brief, the Court's reference to the Progress Clause's usefulness in the context of analyzing an individual work is consistent with Higgins' application of the Clause to an individual work. ${ }^{285}$

Consistency in the interpretation of other terms in the Intellectual Property Clause further suggests that the Progress Clause applies to individual works. Courts analyze whether individual works satisfy the originality requirement, which stems from the Authors and Writings terms in the Intellectual Property Clause. ${ }^{286}$ Courts do not limit the

\footnotetext{
278 Id. (emphasis added).

279 Id.

280 Id. (emphasis added).

281 See id; see also Stiftung v. Renishaw PLC, 945 F.2d 1173, 1180 (Fed. Cir. 1991) ("The utility requirement [which applies to individual patent applications] has its origin in article 1 , section 8 of the Constitution, which indicates that the purpose of empowering Congress to authorize the granting of patents is "to promote progress of . useful arts." (emphasis in the original)). But see Schnapper v. Foley, 667 F.2d 102, 112 (D.C. Cir. 1981) (rejecting argument that "the introductory language of the Copyright Clause constitutes a limit on congressional power").

282140 U.S. $428,431-32$ (1891).

283 Id.

284 See 188 U.S. 239, 248-49 (1903).

285 See id; discussion supra Part 1.C.1.a.

286 See Eldred v. Ashcroft, 537 U.S. 186, 211 (2003) (interpreting Authors and
} 
originality requirement to the statutory regime of the Copyright Act. So if the Progress Clause represents a limitation, there seems no reason to apply that limitation only to the statutory whole in view of the application of other limiting terms in the Intellectual Property Clause to individual works. Such a distinction in the application of terms in the Intellectual Property Clause lacks precedential or reasoned support.

\section{Judicial Rejection of the Innocence Inquiry}

These misconstructions of the Progress Clause culminated in the opinion of one federal case, Mitchell Brothers Film Group v. Cinema Adult Theater - a 1979 Fifth Circuit decision. ${ }^{287}$ Written by Judge John Godbold, Mitchell expressly disavowed the innocence restraint that had governed copyright for nearly two centuries. ${ }^{288}$ As discussed above, courts and scholars prior to Mitchell had recognized an innocence restraint to determine copyright eligibility. ${ }^{289}$ Until Mitchell, the restraint had existed as part of the Progress Clause and as part of the common law, articulated by Supreme Court Justice Joseph Story, copyright scholars Eaton Drone and Horace Ball, and in case law repeatedly throughout the nineteenth and twentieth centuries. ${ }^{290}$ Mitchell decried the centuries of precedent that acknowledged the innocence restraint.

The defendants in Mitchell had copied a motion picture created by the plaintiffs, which the district court had found to be obscene and thereby unfit for copyright protection under the Progress Clause. ${ }^{291}$ The issue on appeal was whether obscenity was eligible for copyright. ${ }^{292}$ The Fifth Circuit held first that the Copyright Act extended to obscene material, and second, that the Progress Clause authorizes Congress to extend that copyright protection. ${ }^{293}$

\footnotetext{
Writings as imposing originality requirement on individual works); Feist Publ'ns, Inc. v. Rural Tel. Serv. Co., 499 U.S. 340, 346 (1991) (same).

287 Mitchell Bros. Film Grp. v. Cinema Adult Theater, 604 F.2d 852 (5th Cir. 1979). Six years earlier, the Ninth Circuit had rejected the argument that false and fraudulent material could not receive copyright protection. Belcher v. Tarbox, 486 F.2d 1087, 1088 (9th Cir. 1973). The courts there relied on judicial incompetence, reasoning that it would create a difficult burden for the court to determine truth. Id. The court did not consider any constitutional question in reaching that holding.

288 See Mitchell, 604 F.2d at 854-60.

289 See discussion supra Part I.B.3, I.C.3-4.

290 See discussion supra Part I.B.3, I.C.3-4.

291 Mitchell, 604 F.2d at 854.

292 Id.

${ }^{293}$ Id. at $858,860$.
} 
Several interpretive errors led to this holding. With regard to the Mitchell court's interpretation of the Copyright Act, I believe it misconstrued congressional silence on the issue of obscenity, given that for over a hundred years prior the silence had not been interpreted as extending protection. Although much more could be said on the correct interpretation of the Copyright Act, this Article addresses only the Progress Clause, so I focus solely on the constitutional arguments of the Mitchell court. In particular, I address two fundamental errors in the court's reasoning that led to its interpretation of the Progress Clause. ${ }^{294}$

\section{Creativity as Copyright's Purpose}

The court's first error was to frame the purpose of copyright in terms of creativity rather than useful knowledge. ${ }^{295}$ The court stated:

The purpose underlying the constitutional grant of power to Congress to protect writings is the promotion of original writings, an invitation to creativity. This is an expansive purpose with no stated limitations of taste or governmental acceptability. Such restraints, if imposed, would be antithetical to promotion of creativity. ${ }^{296}$

The court thus viewed creativity as the ultimate end of copyright. As discussed above, creativity as the focus of copyright fails to suggest any sort of content-based restraint, for all original expression reflects creativity. ${ }^{297}$ More precisely, creativity suggests an absence of the innocence restraint. ${ }^{298}$ The Mitchell court therefore concluded that any

294 Another error in the Mitchell court's analysis was its reliance on the nondiscrimination principle in Bleistein. See id. at 855-56. As discussed above, Holmes directed his nondiscrimination principle to the originality inquiry - not the innocence restraint. See Bleistein v. Donaldson Lithographing Co., 188 U.S. 239, 25052 (1903); discussion supra Part I.C.1. And he engaged in an individual analysis of the work at issue under the Progress Clause. See Bleistein, 188 U.S. at 249. Moreover, Holmes made clear that the nondiscrimination principle contemplated limits. See id. at 251. It was by no means absolute. Id. The Mitchell court, by contrast, introduced a nondiscrimination principle that was entirely absolute, without any qualification or limit. See Mitchell, 604 F.2d at 860. It was so absolute that the court rejected individual analyses of works. See id. Therefore, Mitchell's reliance on Bleistein was simply misplaced. Holmes neither addressed the innocence restraint nor portrayed the nondiscrimination principle as absolute.

295 See Mitchell, 604 F.2d at 856.

296 Id.

297 See discussion supra Part II.A.2.

298 See discussion supra Part II.A.2. 
restraints on content would be "antithetical" to the promotion of creativity, i.e., the purported purpose of copyright. ${ }^{299}$ So by framing the purpose of copyright in terms of creativity, the Mitchell court ignored the innocence restraint that the Progress Clause had historically demanded. Even obscenity is creative.

\section{Necessary and Proper Clause}

The court's second error consisted in its application of the Necessary and Proper Clause to conclude that the Progress Clause allows all original works to receive copyright protection, even those that do not promote Progress. ${ }^{300}$ The court reasoned:

Congress could reasonably conclude that the best way to promote creativity is not to impose any governmental restrictions on the subject matter of copyrightable works. By making this choice Congress removes the chilling effect of governmental judgments on potential authors and avoids the strong possibility that governmental officials (including judges) will err in separating the useful from the non-useful. ${ }^{301}$

Before addressing the merits of the court's Necessary-and-Proper argument, I offer two preliminary observations about the court's reasoning here. First, in setting forth the argument, the court first recited the constitutional end of copyright as promoting creativity. ${ }^{302}$ As noted above, this premise of creativity unquestionably implies the protection of obscenity. Indeed, the creative nature of obscenity is so apparent that the Necessary and Proper Clause need not even be invoked. The court's invocation of that Clause is therefore puzzling given that it portrayed the purpose of copyright as creativity.

Second, more puzzling about the Mitchell court's reasoning in this quotation is its reference to "the useful." 303 To a certain extent, the Mitchell court appears to have recognized useful knowledge when it referred to problems with judges attempting to distinguish "the useful from the non-useful." 304 That is, the court here seemed to recognize that the Progress Clause demands usefulness. ${ }^{305}$ And not merely the

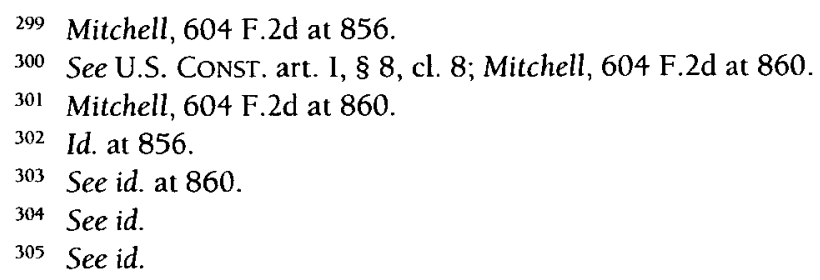


sort of usefulness that examines compositional value, for obscenity would satisfy that end through its inherent creativity. The court's reference to the "non-useful" must imply the innocence restraint. ${ }^{306}$ Yet at the same time, the court viewed innocence as a standard that stood in the way of the ultimate end of copyright, promoting creativity. ${ }^{307}$ The court thus seemed to equivocate on the purpose for copyright: outwardly declaring creativity yet tacitly acknowledging usefulness and its innocence restraint.

Regarding the merits of the court's Necessary-and-Proper argument, the court reasoned that Congress may deem it necessary and proper to protect works that are non-useful in order to avoid chilling works that are useful. ${ }^{308}$ To a point, this makes sense. If copyright were to categorically preclude all non-useful works, this might chill the creation of some useful works: authors might refrain from creating works on the edge of an innocent subject matter, or for that matter, on the edge of creativity. The potential chilling is reason to protect those which are close to, and in some cases even cross, the line of useful knowledge. As the court rightly observed, encouraging the production of wheat requires the protection of chaff. ${ }^{309}$

The court, however, did not stop there. It deemed reasonable the categorical extension of copyright to all non-useful works. ${ }^{310}$ Its logic was that if barring all non-useful works might chill some useful works, then it is reasonable to protect all non-useful works without inquiry into their individual content. ${ }^{311}$ In effect, the Mitchell court held reasonable the proposition that incenting all works that fall outside

306 The court made a similar suggestion in another part of its opinion, commenting: "The pursuit of creativity requires freedom to explore into the gray areas, to the cutting edge, and even beyond." Id. at 856 . Beyond what? Beyond creativity? Surely not. The court's reference to the "freedom to explore into the gray areas" implies a standard that defines an area to be "gray" - a standard that gives meaning to "beyond." The court appears to have tacitly recognized a standard that calls into question the eligibility of obscenity, or in other words, a standard of innocence.

307 See id.

308 See id. at 860; see also United States v. Comstock, 130 S. Ct. 1949, 1956 (2010) (explaining that the Necessary and Proper Clause justifies congressional statute where the statute is "rationally related to the implementation of a constitutionally enumerated power").

309 See Mitchell, 604 F.2d at 860 . For this reason, copyright protection should be presumed absent a showing that a work does not satisfy the innocence standard. Doubt should favor copyright protection - just as it does in free speech cases. See discussion infra Part III.A.

310 See Mitchell, 604 F.2d at 860.

311 See id. 
the Progress Clause is necessary to incent some works that fall within it. $^{312}$

This proposition does not appear reasonable. Just as a categorical preclusion of copyright for non-useful works appears unreasonable, so too does the categorical extension of copyright for non-useful works appear unreasonable. Barring copyright for non-useful works that fall well outside the purview of usefulness does not seem to pose any practical chilling, from either the perspective of compositional value or moral innocence. It appears unreasonable to believe that the law must incent the creation of every work that impedes progress in order for the law to incent works that promote progress. If even one work that impedes progress fails to incent a work that promotes progress, then a categorical extension of all works is unjustified. Thus, categorically extending copyright to all works that fall outside the Progress Clause, without any individual inquiry, does not appear reasonable. It appears to exceed Congress's power, even under a broad reading of the Necessary and Proper Clause. ${ }^{313}$

Thus, applying the Necessary and Proper Clause makes sense to the extent that courts examine works on an individual basis and determine that a work is sufficiently close to the line of usefulness (specifically, innocence) to give a copyright monopoly. In short, doubt regarding whether a work is not innocent should favor its copyright eligibility. On the other hand, it does not make sense to apply the Necessary and Proper Clause in a way that bars any inquiry into innocence at all. Such an application would strip the Progress Clause of any meaning, and accordingly, appear unreasonable.

\section{The Progress Clause as a Standard for Copyrightable CONTENT}

As discussed above, several modern interpretations of the Progress Clause run counter to its historical application. ${ }^{314}$ The interpretation of the Clause as focusing on general knowledge or creativity has made the innocence inquiry seem entirely unnecessary. ${ }^{315}$ Similarly, construing the Clause as an impotent preamble moots the issue of

\footnotetext{
312 See id.

313 Cf. Jeanne C. Fromer, The Intellectual Property Clause's External Limitations, 61 DukE L.J. 1329, 1383-85 (2012) (arguing that the Necessary and Proper Clause does not enable Congress to promote Progress through means not specified in the Intellectual Property Clause).

314 See discussion supra Part II.

315 See discussion supra Part II.A.
} 
innocence. ${ }^{316}$ Several commentators have interpreted Bleistein as overthrowing the innocence inquiry. ${ }^{317}$ And at least one court, the Fifth Circuit in Mitchell, has relied on the Necessary and Proper Clause to reject innocence altogether. ${ }^{318}$ In short, modern interpretations have employed various legal rationales to read innocence out of the Progress Clause. And this implies that as a constitutional matter, courts must refrain from even asking the question of whether content, or its effects, may disqualify expression from receiving a copyright. The modern interpretations suggest that the Constitution is blind to content, such that courts may no longer draw a line of moral innocence. Courts can't even ask the question.

Tellingly, none of these modern interpretations has definitively prevailed. Several judges have questioned the legitimacy of the Mitchell decision. ${ }^{319}$ Some scholars have recognized the Progress

316 See discussion supra Part II.B.

317 See sources cited supra note 11.

318 See discussion supra Part Il.C.

319 The District of Massachusetts recently questioned the Mitchell holding in Liberty Media Holdings, LLC v. Swarm Sharing Hash File, 821 F. Supp. 2d 444, 447 n.2 (D. Mass. 2011). The Liberty court characterized the issue of whether pornography was copyrightable as "unsettled in many circuits," and it further noted that before Mitchell, copyright was "effectively unavailable for pornography." Id. That court, however, did not rule contrary to Mitchell because the issue was not before it. See id. The Southern District of New York has also questioned the Mitchell holding. In 1998, it refused to enforce a copyright for obscene material, and in so doing, the court noted: "It is far from clear that the Second Circuit will follow the Fifth and Ninth Circuits in rejecting the argument that obscene material is entitled to copyright protection." Devils Films, Inc. v. Nectar Video, 29 F. Supp. 2d 174, 176 (S.D.N.Y. 1998). More recently in 2012, the Southern District again cast doubt on the Mitchell holding, stating: "the Court recognizes that, if the [expression] is considered obscene, it may not be eligible for copyright protection." Next Phase Distrib. v. John Does 1-27, 284 F.R.D. 165 (S.D.N.Y. 2012).

On the other hand, several courts and well-respected commentators have agreed with the Fifth Circuit's Mitchell decision. See Flava Works, Inc. v. Gunter, 689 F.3d 754, 755-56 (7th Cir. 2012) (citing to Mitchell for its statement in dicta that "the prevailing view is that even illegality is not a bar to copyrightability"); Dream Games of Ariz., Inc. v. PC Onsite, 561 F.3d 983, 990-91 (9th Cir. 2009) (relying on Mitchell to extend copyright to gambling computer program that furthered illegal activity); Jartech, Inc. v. Clancy, 666 F.2d 403, 405 (9th Cir. 1982) (relying on Mitchell to recognize copyright in obscenity); Nova Prods. v. Kisma Video, Inc., Nos. 02 Civ.3850(HB)(RLE), 02 Civ.6277(HB)(RLE), 03 Civ.3379(HB)(RLE), 03 Civ.4259(HB)(RLE), 2004 U.S. Dist. LEXIS 24171, at *10 (S.D.N.Y. Nov. 30, 2004) (describing Mitchell as a "well-reasoned and scholarly" opinion); NIMMER \& NIMMER, supra note 13, \& 2.17 (describing the court's reasoning in Mitchell as "the most thoughtful and comprehensive analysis of the issue"); 1 PATRY, COPYRIGHT LAW AND PRACTICE, supra note 28, at 126-27 n.28 (relying on Mitchell for the proposition that copyright does not apply to individual works). 
Clause as a constitutional limitation. ${ }^{320}$ Most federal circuit courts, along with the Supreme Court, have not voiced an opinion on whether the Progress Clause entails an innocence inquiry. In short, none of the modern interpretations have settled the law.

In view of the failure of any of the modern interpretations to prevail, the law appears to contemplate the possibility for judges to question a work's content in deciding copyright eligibility. That is, the problematic nature of the modern constructions gives place for an interpretation of the Progress Clause that facilitates content review. Judicial examination of content would not offend historical cannons of constitutional construction. ${ }^{321}$ Therefore, courts have constitutional authority to conclude that where expression crosses a line of innocence, the expression fails to promote Progress. Courts may conclude that expression is not worth incenting, and thereby does not merit the government subsidy of a copyright monopoly.

Although this Article observes problems in the modern interpretations, it stops short of engaging in a full discussion of the sort of content discrimination that courts should now employ. A full discussion I leave for another article, which will address the criteria that should inform whether courts should award a copyright monopoly. That discussion will consider the effectiveness of those criteria at promoting progress in light of changing social values, the role of judges as gatekeepers of those values, and the criteria's effect on speech interests of content creators. But this Article is not that discussion. I limit my discussion here to the question of whether the history of the Progress Clause contemplates the issue, and in considering that question, I offer here a summary preview of the theory and criteria that the Clause should now contemplate, consistent with that history. That theory and those criteria lead to the conclusion that the Progress Clause should return to its historical meaning of useful knowledge, requiring that content be innocent of immoral content, where the immoral is defined according to modern-day values. ${ }^{322}$

320 See Oliar, Making Sense, supra note 12, at 1810-16; Snow, supra note 12, at 27576; Walterscheid, Within the Limits, supra note 258, at 326.

321 See discussion supra Part I.

322 Cf. Michael J. Madison, Beyond Creativity: Copyright as Knowledge Law, 12 VAND. J. ENT. \& TECH. L. 817, 819-25 (2010) (arguing against creativity as a standard to measure copyright and for a definition of knowledge that raises difficult linedrawing questions for policymakers).

Courts may adopt this interpretation by either applying both Science and useful Arts to copyright, as courts have done in the past, see, e.g., Higgins v. Keuffel, 140 U.S. 428,431 (1890), or alternatively, applying only Science to copyright, as they presently 


\section{A. A Value-Based Theory of the Progress Clause}

The theory of the Progress Clause should rest upon its inherent call for normative judgment. Its outward question of whether a work promotes the Progress of Science or useful Arts appears laden with value judgment. ${ }^{323}$ Consider the operative words individually. Whether a work promotes or impedes Progress turns on a value judgment about whether the work moves forward Science and useful Arts. The same can be said about whether a work amounts to Progress or regress. As for Science, unlike its modern misconstruction as general knowledge, the original meaning calls for a value judgment about whether content is worthy of study. ${ }^{324}$ And useful Arts calls for a value judgment about whether a work is in fact useful. Hence, the Progress Clause cries out for value judgments to answer its ultimate question of whether the law should incent particular content. The Clause is entirely normative.

The normative demand of the Progress Clause relies on the premise that content discrimination can be a good thing. Simply put, the Clause limits Congress in extending copyright to that which promotes Progress, but no more than that. That which falls outside of promoting Progress is not worth incenting. Applied correctly, this premise makes sense. Content discrimination can protect innocent members of the public from harm. It can preserve government resources for incenting works that demonstrate at least a modicum of social value rather than those that would regress Science and useful Arts. In short, resources that the government invests in creating and maintaining a monopoly system should not advance that which is wasteful, harmful or

do, see, e.g., Golan v. Holder, 132 S. Ct. 873,888 (2012), but with a narrower meaning of Science - i.e., useful knowledge rather than general knowledge. Either way, the meaning of the Progress Clause should imply an innocence restraint on the subject matter of copyright. Should courts reach this meaning by reading useful Arts as applying to copyright law, this hermeneutical move need not affect the contours of patent law, which presently courts limit to useful Arts. The term useful Arts suggests a useful application of the theoretical knowledge from Science, and patent is confined to applications of knowledge, whereas copyright encompasses both theoretical knowledge and the expression of its useful applications. See Snow, supra note 12, at $298 \&$ n.144.

323 See U.S. CONST. art. I, § 8, cl. 8; Zimmerman, The Story of Bleistein, supra note 11 , at 88 (describing plain language of Progress Clause as "precedent for the proposition that copyright was available only for works that met some basic standard of worthiness"); Yen, supra note 128, at 247 (observing that plain language of Progress Clause intuitively suggests that judges should be conscious of aesthetics in copyright cases).

${ }^{324}$ See Snow, supra note 12, at 306. 
otherwise regressive to society. ${ }^{325}$ Content discrimination can further the purpose of copyright. Thus, the Progress Clause should contemplate a theory that argues against a universal application of copyright. There must be some baseline - some "narrowest and most obvious limits," in the words of Justice Holmes - that invokes content discrimination. ${ }^{326}$ Courts should recognize that it is possible to award copyright monopolies too liberally.

On the other hand, courts should recognize the over-arching admonition of Justice Holmes. ${ }^{327}$ It is possible for courts to apply copyright monopolies too conservatively. If copyright eligibility turns on entirely subjective values in defining the terms promote, Progress, Science, and useful, the constitutional system of copyright will fail to incent much expression that a substantial portion of society holds valuable. Therefore, courts must exercise content discrimination with caution, denying copyright not on their own personal views, but rather on commonly held values of society. Absent a commonly held value suggesting that a work should not be incented, a work should be presumptively copyrightable. Doubt should favor copyright. Thus, at the same time that courts should read the Progress Clause as facilitating content review, courts should be confident that common social standards dictate the ineligibility of particular content before denying copyright.

\section{B. Narrow and Obvious Limits of Innocence}

Courts might weigh a variety of factors as they assess whether expressive content offends social values, fails to promote progress, and thereby does not merit a copyright monopoly. Two general indicia that courts should consider are first, an absence of social value, and second, a presence of social harm. Although I do not provide a full discussion of these factors here, nor argue that they necessarily determine the issue, I offer them as possible factors that courts might consider, in preview of a fuller discussion.

\section{Absence of Social Value}

Courts might consider the absence of social value in expression. The relevant inquiry would be similar to that found in speech law: whether

325 See generally Yen, supra note 128 , at 248 ("[W]hen courts interpret the contours of copyrightable subject matter, they single out certain works for a special economic subsidy.").

326 See Bleistein v. Donaldson Lithographing Co., 188 U.S. 239, 251-52 (1903).

327 See id. 
expression "lacks serious literary, artistic, political, or scientific value"? ${ }^{328}$ Yet unlike speech law, expression that lacks value for the purpose of denying a copyright monopoly need not be so lacking as to deprive it of protection from government censorship. ${ }^{329}$ As a practical matter, this would mean that courts may consider whether a significant segment of society deems this expression lacking, rather than society as a whole. If a significant segment of society does deem expression so lacking, courts should be able to weigh this fact in the overall analysis of whether the expression is worthy to incent. And this fact would weigh heavier in that analysis based on the greater proportion of society that recognizes a lack of serious value in the expression.

Two examples illustrate how courts might apply this factor. Consider musical lyrics that constitute hate speech, vilifying or disparaging a particular racial minority, for instance. A court should be able to observe that such lyrics offend the commonly held value of racial equality. This value is apparent as a theme throughout constitutional jurisprudence and statutory law generally, so the argument would be strong that a large segment of society adheres to this value. Furthermore, if it could be demonstrated that a significant segment of society would consider the lyrics in question as contradicting this social value of racial equality, this fact would suggest that society does not value the expression at issue. A court

${ }^{328}$ See Miller v. California, 413 U.S. 15, 24 (1973) (explaining test for legal obscenity).

329 This raises a question regarding the role of copyright in speech theory. Should the same standard employed to determine whether expression lacks value in free speech law also apply in copyright law? The short answer is no: although the Progress Clause supports the theory of the Free Speech Clause, the language of the Progress Clause suggests that its scope is more restricted than the Free Speech Clause. Specifically, the Progress Clause targets expression that is expressly restricted to that which promotes Progress, whereas the Free Speech Clause targets all expression without any express restriction, which necessitates that any exception to the presumptive universal application be narrow and restrictive.

This answer, however, is not altogether satisfactory. The marketplace of ideas theory appears to underlie copyright as much as it does free speech law. Indeed, the author of that theory is Justice Holmes, who also penned Bleistein. See Abrams v. United States, 250 U.S. 616, 630 (1919) (Holmes, J., dissenting). Hence, on the issue of copyright's role in fostering free speech, there is much more to be discussed. See Ned Snow, Discouraging Speech by Denying Copyright, available at http://ssrn.com/ abstract=2343931 (discussing speech interests of content creators with regard to content-based restrictions in copyright). This article, however, does not take up that discussion. It relies on the assumption that the Progress Clause is narrower in scope than the Free Speech Clause, postponing a full discussion of this issue for another article. 
might make this determination as a matter of law only if no reasonable trier of fact could construe the lyrics otherwise, namely, only if the lyrics clearly demonstrated an animus toward the racial minority. Lacking social value, such lyrics might not be eligible for a copyright monopoly.

Extremely violent video games might also raise questions of content value. With growing public concern over mass shootings in public places, large segments of society may find those video games lacking in value. ${ }^{330}$ Their emphasis on violence seems to condone behavior that should not be valued. Some would argue, then, that their flippant portrayal of violent atrocities indicates their lack of value, and that courts should be able to consider this fact. This is not to say, of course, that social value is entirely absent from those games. The Supreme Court made that clear only a few years ago in Brown $v$. Entertainment Merchants Ass'n. ${ }^{331}$ Yet social value sufficient to merit protection from government censorship does not necessarily imply social value sufficient to merit endorsement by government subsidy of copyright. ${ }^{332}$ Despite the large numbers of gamers who might disagree with the view that those games offend a commonly held value against violent behavior, courts should be able to consider the fact that a significant segment of society deems some games so violent that they offend that value.

\section{Presence of Social Harm}

Often related to the absence of social value is the presence of social harm. Expression that causes harm to society should be viewed as inconsistent with the constitutional mandate to promote Progress. As the harm becomes more pronounced - especially affecting innocent third parties - and as the causal link between that harm and the expression becomes more direct, this factor should weigh heavier in the analysis. Courts should therefore be able to consider the likelihood and severity of harm that expression might cause for individuals who either are entirely innocent third parties or otherwise unaware of the harms associated with the expression.

330 See, e.g., Lou Kesten, Shooting Renews Argument Over Video-Game Violence, U.S. News \& WORLD REPORT (Dec. 19, 2012), http:/www.usnews.com/news/business/ articles $/ 2012 / 12 / 19 /$ shooting-renews-argument-over-video-game-violence (discussing public concern over violent video games).

331131 S. Ct. 2729, 2733 (2011).

332 See supra note 329 and accompanying text. 
One indication of social harm might be a nexus between the expression at issue and criminal activity. Presumptively, criminal activity is socially harmful, and so expression that leads to that activity suggests its failure to promote Progress. Consider an author who offers gambling software for sale in jurisdictions that condemn gambling practices as illegal. ${ }^{333}$ This situation suggests a strong causal link between the expression and the criminal activity of using the software. And the fact that the jurisdiction has made the activity criminal should create a presumption that the consequence of the expression is socially harmful. Taken together, these facts suggest that the social-harm factor would weigh against awarding a copyright monopoly. ${ }^{334}$

Other indicia of social harm might be empirical evidence suggesting that the use or production of particular expression results in a socially undesirable outcome. The pornography context provides several examples. ${ }^{335}$ Evidence demonstrating that the production of certain pornographic expression commonly results in the transfer of sexually transmitted diseases should suggest a basis for questioning its copyright eligibility. ${ }^{336}$ Consider also evidence that a person engaged in sexual acts is unaware that those acts are being filmed: from a privacy standpoint, sex tapes of unknowing subjects suggest a socially undesirable outcome. ${ }^{337}$ Similarly, a socially undesirable outcome may be inferred from evidence that certain pornographers have employed underage models - legally unable to consent. ${ }^{338}$ Hence, the conversation between a pornographer and his willing audience often poses social harms to unknowing or underage subjects, or even the public at large - outcomes that appear inconsistent with promoting

333 See, e.g., Dream Games of Ariz. v. PC Onsite, 561 F.3d 983, 990-91 (9th Cir. 2009) (extending copyright to gambling computer program that furthered illegal activity). This scenario raises the issue of whether the expression would be copyrightable in jurisdictions that do not punish gambling. Although 1 do not exhaustively treat this issue, I give my opinion that where an author has targeted a jurisdiction that does prohibit the activity, his or her conduct suggests a disregard for the law, and accordingly equity demands that this sort of conduct should not be rewarded. In that situation, it would not seem appropriate to award copyright in any jurisdiction. The situation is different, however, where the software enters into the jurisdiction outside of the author's control. I do not address whether a court might recognize copyright in only some jurisdictions.

334 This result would be in opposition to that reached in id. at 990-91.

335 For a persuasive discussion of harms present in the pornography context, see generally Ann Bartow, Copyright Law and Pornography, 9l OR. L. REV. 1 (2012).

336 Id. at $46-47$.

337 Id. at $44-45$.

338 Id. at 41 . 
Progress. ${ }^{339}$ Courts should be able to consider the presence of such social harms in determining whether content is ineligible for copyright under the Progress Clause.

\section{CONCLUSION}

For nearly two centuries, the Progress Clause imposed a contentbased standard for copyright eligibility. Although initially this standard was highly restrictive, courts soon began reading the Progress Clause as conveying a liberal standard. Expression promoted Progress if it imparted useful knowledge, and useful knowledge required only minimal compositional value and a subject matter that was innocent. This liberal standard governed copyright through most of the nineteenth and twentieth centuries. Bleistein did not change it.

Despite the long history of this standard, modern courts and scholars have questioned its continued necessity. Although compositional value remains a requirement in the originality doctrine, the requirement for an innocent subject matter has been cast aside by many. This ignorance of innocence has occurred through various means. Some have rewritten the standard of the Progress Clause from useful knowledge to general knowledge. Some have shifted the focus of copyright from promoting Progress to promoting creativity. Some have re-interpreted the Progress Clause as an ineffective preamble. Some have expressly rejected innocence as a constitutional basis for denying copyright. In sum, a few modern courts and many commentators have unsettled the constitutional requirement for innocence in copyright.

Today this issue is reaching a critical point. If nothing is done, the view of the minority will become settled law of the majority. The silence of the Supreme Court and most circuits on this issue will soon suggest their tacit acceptance of the flawed Mitchell decision. This cannot be. To protect against social harms, the Progress Clause must set narrow and obvious limits that define boundaries of innocent

339 Violent video games might also be viewed as posing social harm sufficient to challenge their copyright eligibility. Studies demonstrate a correlation between participation in certain video games and future tendencies toward violent behavior. See Brown v. Entm't Merchs. Ass'n, 131 S. Ct. 2729, 2767-68 (2011) (Breyer, J., dissenting). Although courts have deemed the causal between the expression and the future behavior as insufficient to give rise to tort liability, this does not imply that the link is insufficient to refrain from awarding a monopoly through copyright. Cf. Sanders v. Acclaim Entm't, Inc., 188 F. Supp. 2d 1264, 1273-74 (D. Colo. 2002) (recognizing social utility in violent video games to conclude that video game manufacturers were not negligent based on violent actions of its participants). 
content. Copyright must renew its role of promoting Progress. Indifference to innocence leads only to regress. 